"نشريه علوم زراعى ايران"

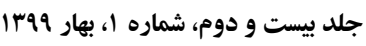

مقاله يُوهشى

اثر روشهاى خاكورزى و كاشت بر ويزكى هاى فيزيكى خاكى، عملكرد دانه و راندمان تبديل برنج (Oryza sativa L.

Effect of tillage and planting methods on soil physical properties, grain yield and milling recovery of rice (Oryza sativa L. cv. Hashemi)

$$
\text { مينا ابر اهيمى '، مجيد مجيد يان و محمدرضا عليز اده؟ }
$$

جצ'ינים

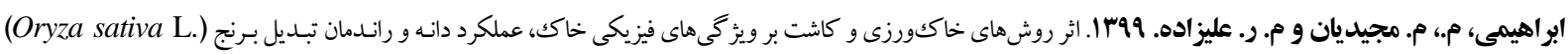

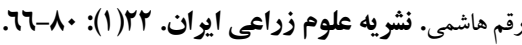

به منظور بررسى اثر روشهاى خاككورزى وكاشت بر ويز كىهاى خاكى، عملكرد دانه و خصوصيات تبديل بـرنج، آزمايشى بــه صورت كرتهاى خرد شده در قالب طرح بلوككهاى كامل تصـادفى بـا سـه تكـرار در دو سـال زراعسى تحقيقات برنج كشور (رشت) اجـرا شـــ تيمارهـاى آزمايشـى شـامل روشهــاى خـاكورزى در سـه سـطح؛ روتـارى تراكتـورى، خاكى همزن مرسوم تيلرى و پادلر دوار تيلرى، به عنوان عامل اصلى و روشهاى كاشت در سه سطح؛ نشاكارى دسـى، نشـاكارى بـاـ ماشين نشاكار و كاشت مستقيم بذر در خاكى غرقاب، به عنوان عامل فرعى بودند. نتايج تجزيه واريانس مر كب دادهها نشـان داد كـــ تيمارهاى خاككورزى اثر معنى دارى بر عمق نفوذ مخروط سقوطى و جعَالى خاكى داشتند. بيشترين عمـق نفـوذ مخـروط سـقوطى

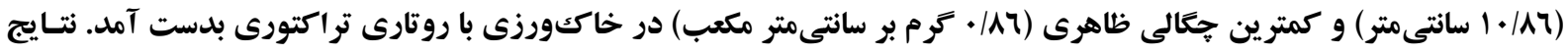

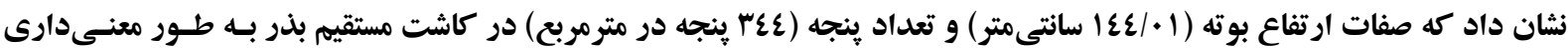

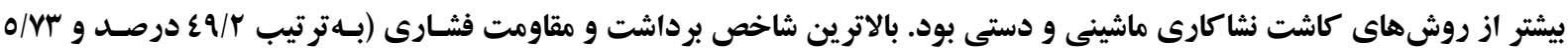
نيوتن) در نشاكارى ماشينى بدست آمد كه تفاوت معنىدارى با كاشت مستقيم بذر و نشاكارى دستى داشت. حداكثر تعداد خوشه در

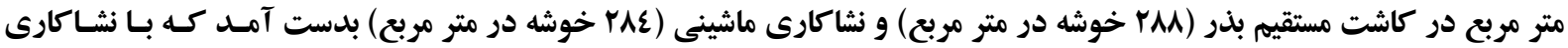
دستى ( الحץ خوشه در مترمربع) تفاوت معنىدارى داشت. روشهاى خاكىورزى، كاشت و برهمكنش آنها اثر معنسىدارى بـر ميـزان دانه هاى سالم، خرد و راندمان تبديل نداشتند. نتايج اين آزمايش نشان داد كه در خاككورزى با استفاده خاكىهمزنهـاى تيلـرى و روشهاى كاشت نشاكارى ماشينى و كاشت مستقيم بذر مىتوان علاوه بر حفظ ويزگى هاى فيزيكى خاكى، عملكرد دانسه مناسـبى در برنج بدست آورد.

وازههاى كليدى: برنج، خاكورزى، كاشت مستقيم بذر، مقاومت فشارى و نشاكارى ماشينى.

اين مقاله مستخرج از رساله دكترى نگًارنده اول مى باشد.

تاريخ دريافت: 1\%

ا 1- دانشجوى دكترى دانشكده علوم كشاورزى دانشكاه كيلان.

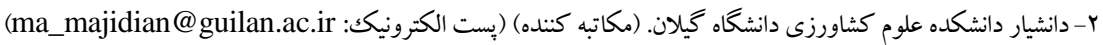

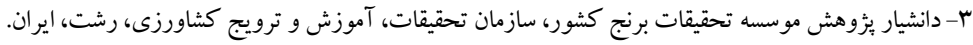


نسوع دسـتخاه خـاككورز تيلـرى شـامل خـاكك همـزن مرسوم، روتيوار تيلرى و بادلر مخروطى با يكك و دوبـار

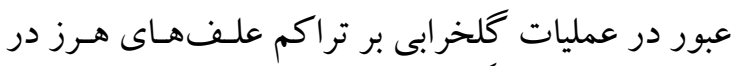

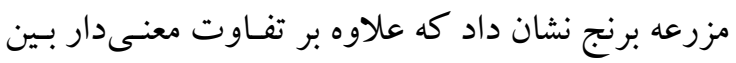

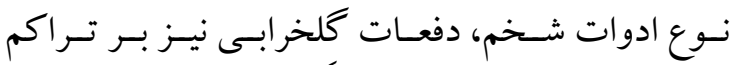
علف هاى هرز تأثير داشتند. در زراعت برنج استقرار گياهجه يكك مرحله كليدى دئي

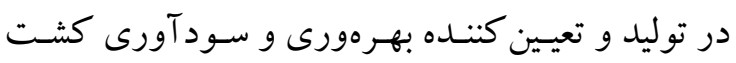

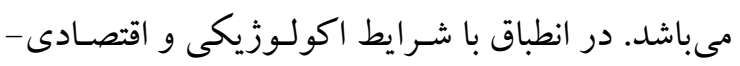

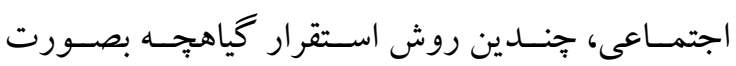

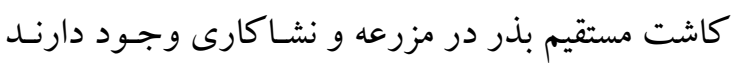

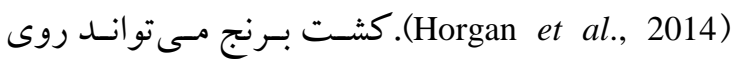

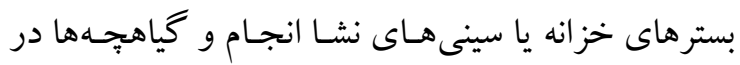
سن هاى مختلـف بصـورت دستى (سـنتى) و يـا ماشـينى

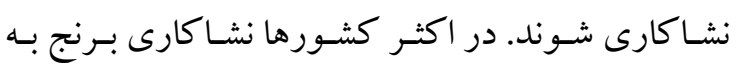

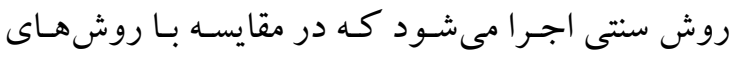

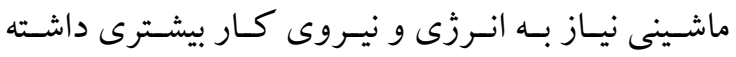

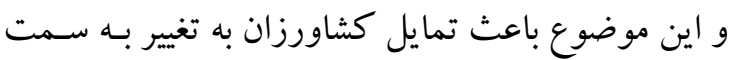

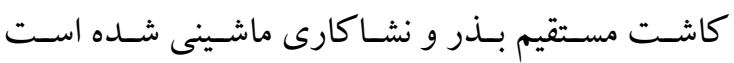
(Chen et al., 2017). كاشت مستقيم بذر بـرنج در حسال

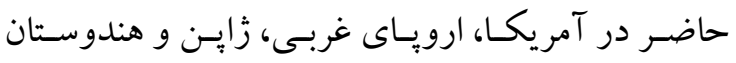

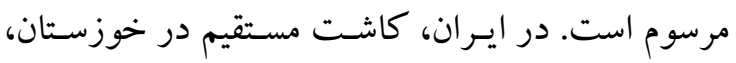

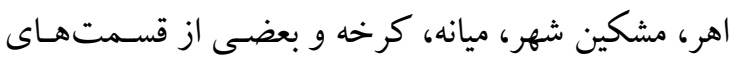
آذربايجان شرقى رايج اسـت. كاشـت مستقيم بـه دليـل

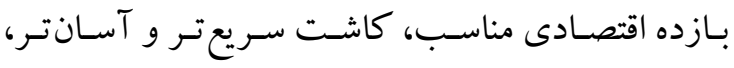

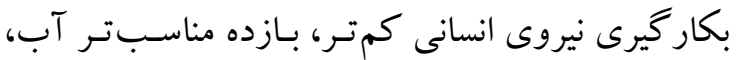

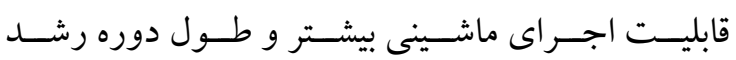

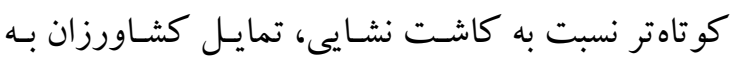

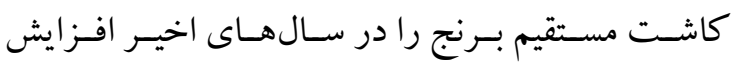

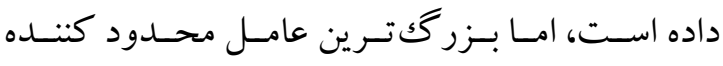

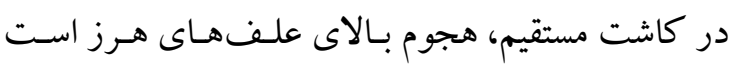

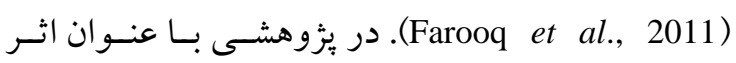
نرخ بذر، مديريت علفهاى هرز و روش استقر ار بـــر

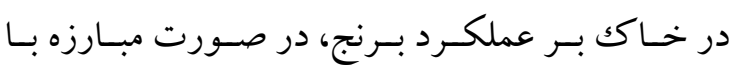

\section{مقدمه}

بـرنج (Oryza sativa L. يكى از مهم تـرين غـلات

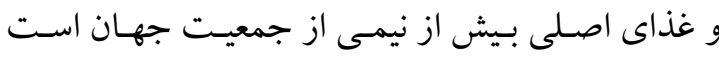

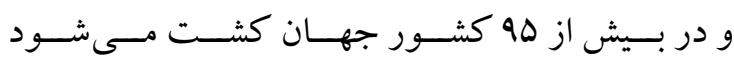

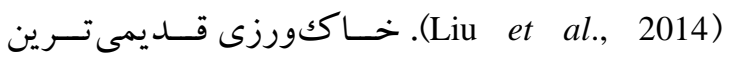

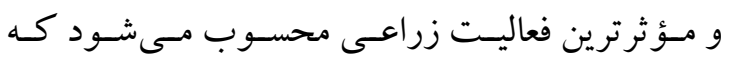

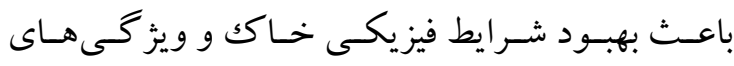

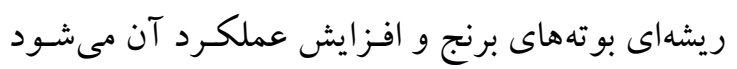

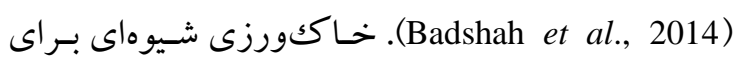
همزدن خاكك و فراهم شدن شرايط بـراى كاشـت كيـاه

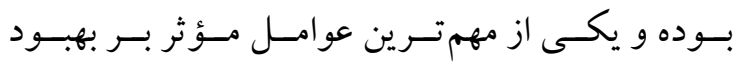

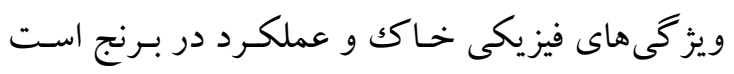

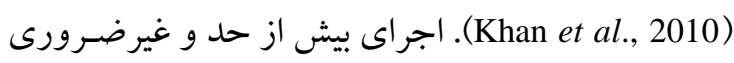

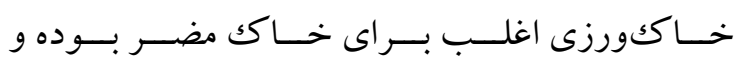

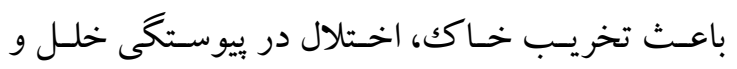

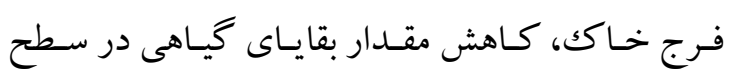
خاكى و به طور كلى كـاهش كيفيـت خـاكك مسى خـردد (Yaduvanshi and Sharma, 2008) براى اجر ایى خاككورزى بر اساس شـرايط هـر منطقـهـ از

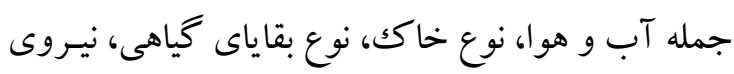
كششى در دسترس و غيره، در بسيارى از منـاطق دنيـا و

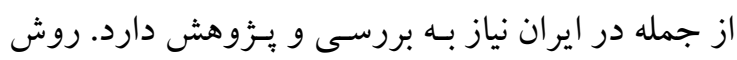

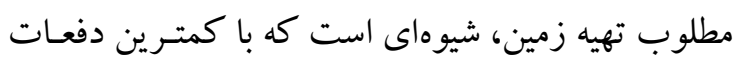

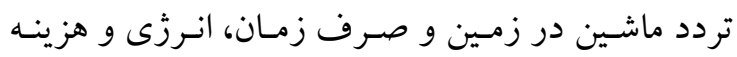

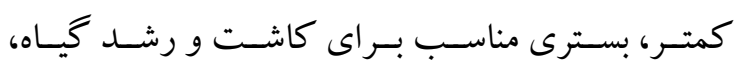

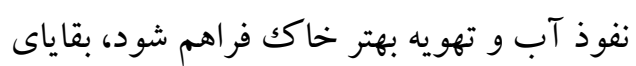

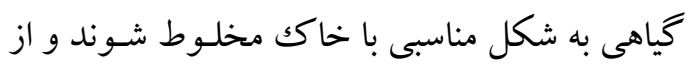

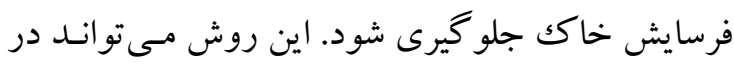

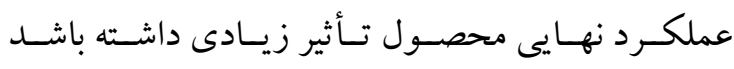
(Habibi-Asl and Gilani, 2014)

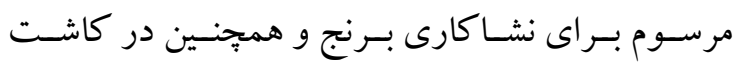

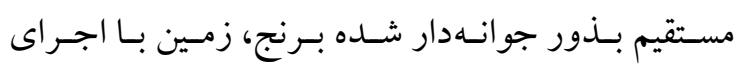
كلخر ابى خاكك آماده مى شود (Alizadeh, 2015). نتايج

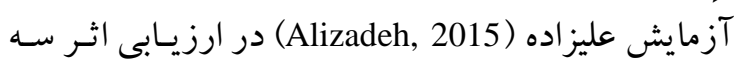


" اثر روشهاى خاككورزى و كاشت.... مينا ابراهيمى و همكاران، 99"ا، •199"

خاككورزى) داشت. علا و همكاران (Ala et al., 2014)

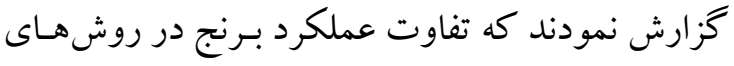
كاشت عمدتا مربوط به مديريت علف هاى هـرز بـ بـوده و و جنانجه علفهاى هرز كنترل شوند، بين دو شيوه كاشت مهري

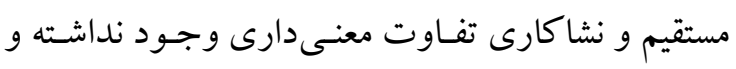
حتى در برخى مواقع عملكـرد دانـه در كاشـت مستـقيم بيشتر بود. گانخوار و همكاران (Gangwar et al., 2008) نيز كز ارش كردند كه بوته هاى برنج در كاشـت مستـقيم بذر تجمع ماده خشك ساقه و ريشـه بيشـترى نسـبت بـهـ بوتههاى رشد يافته در نشاكارى دستى و ماشينى داشتند.

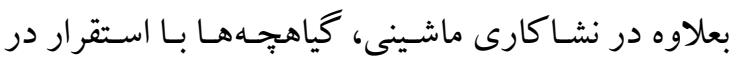

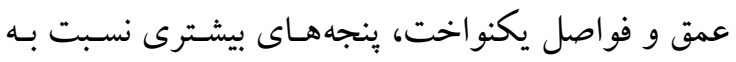
نشاكارى دستى توليد كردند. با توجه به اين كه كشاورزان در مناطق شمال كشـور

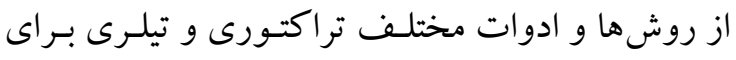
عمليات آمادهسازى زمين برنج استفاده مى كنند، انتخاب

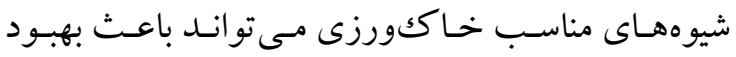

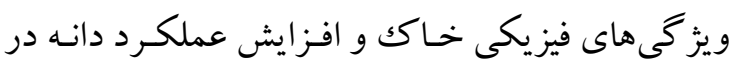
واحد سطح شود. با توجه به اينكه اطلاعـات نسبتا قابـل توجهى در خصوص اثر كاشت مستقيم بذر و نشـاكارى برنج وجود دارد، اما تحقيقات اندكى درباره اثرات توام روشهاى خاككورزى و كاشت بر عملكرد دانـه انجـام

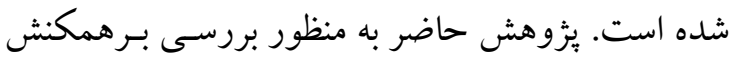
روشهاى خاككورزى و كاشت بر ويز گهى هاى خاكى و

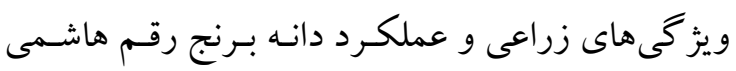

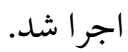

\section{مواد و روشها}

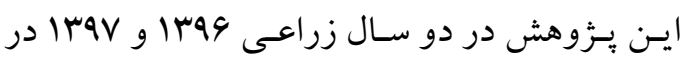

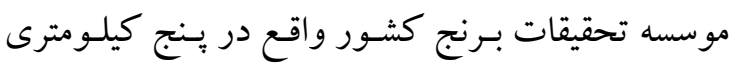

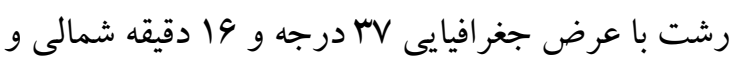

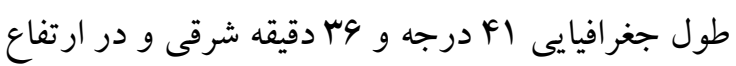
هفت متر بايين تر از سطح درياى آزاد اجرا شـد. قبـل از

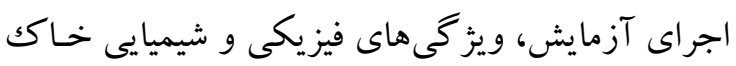

علف هاى هرز، عملكـرد دانـه در روش كاشـت مستقيم بــا ماشـين، مشــابه روش نشــاكارى بــود و اسـتفاده از

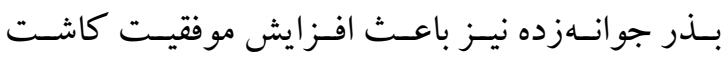
مستقيم شــ (Sinha et al., 2008). ايـوانى و همكـاران در مقايسه روش هـاى كاشـت (Ivani et al., 2014) كزارش كردند كه بين نشاكارى دستى، كاشت مستقيم

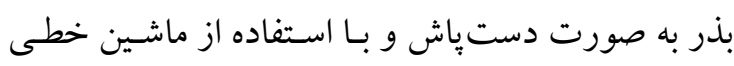

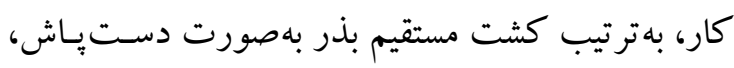

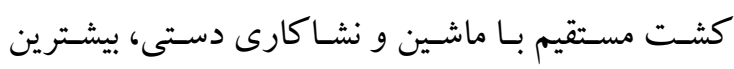

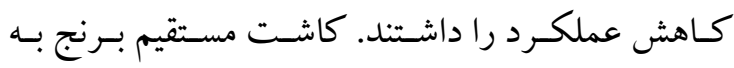

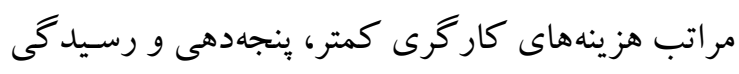

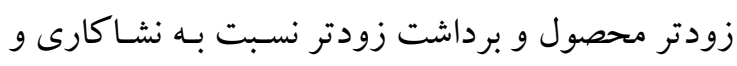

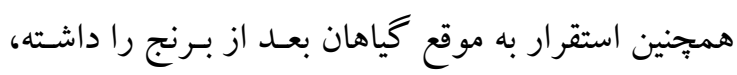

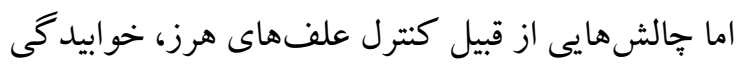

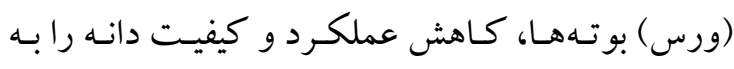

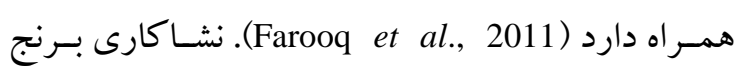
علف هاى هرز را بهتر كنترل مى كند، اما بوتـهــا در اثر

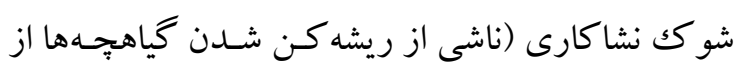

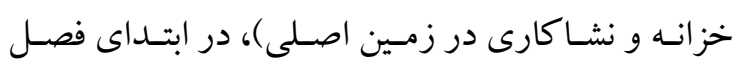

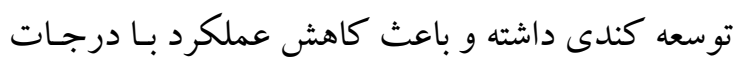

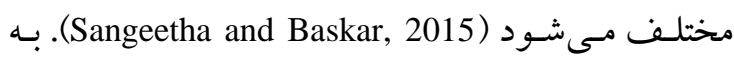

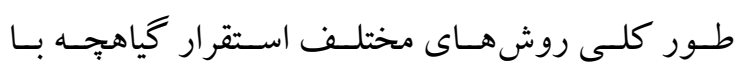
روش هـاى مختلـف زراعى از نظـر خـاككورزى اوليهه،

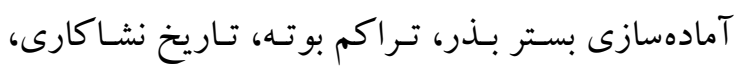
وجسين و مــيريت آب همـراه اسـت (Li et al., 2016).

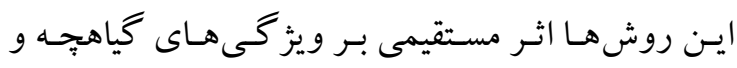

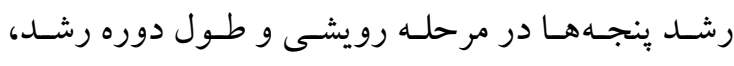

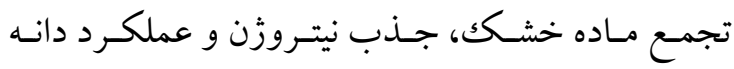

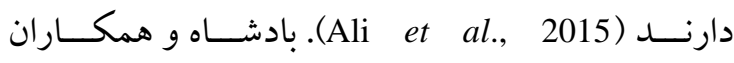
(Badshah et al., 2014)

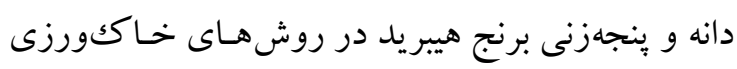

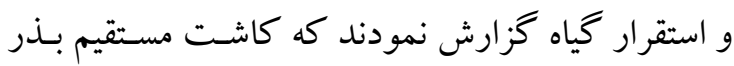

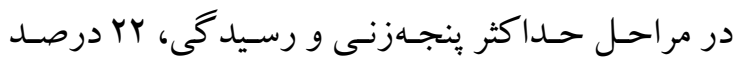

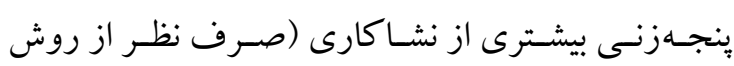


برنج بـومى رقـم هاشـمى اسـتفاده شـد. ايـن رقـم يابلنـد

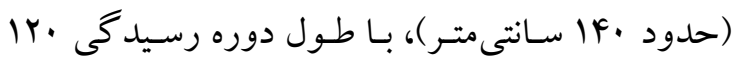

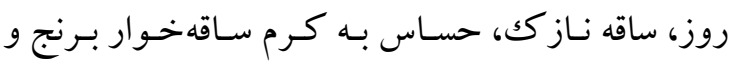

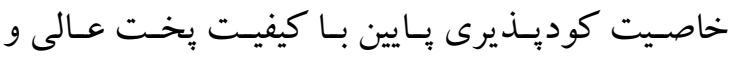
بازاريسندى خوب، به عنوان يكى از ارقـام مـورد بِ بــند

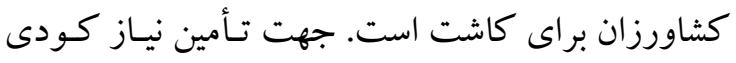

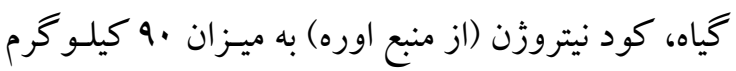

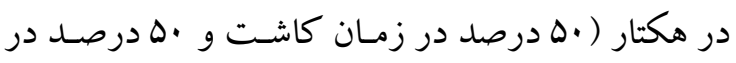

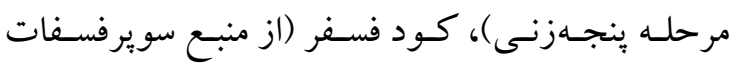

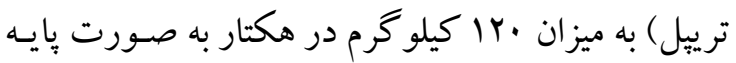

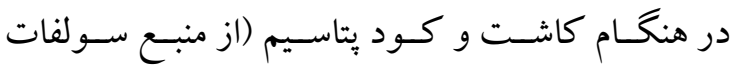

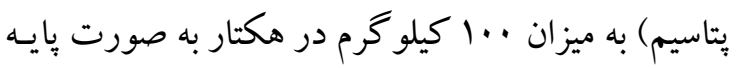

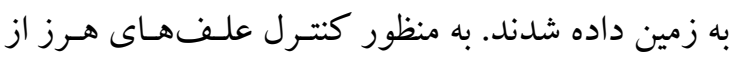
علف كث بو تاكلر به مقدار مناسب (سه ليتر در هكتار ) به صورت بِ از كاشت و وجسين دستى استفاده شـد.

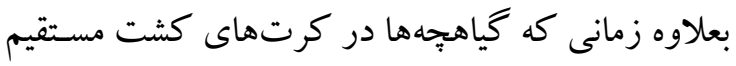

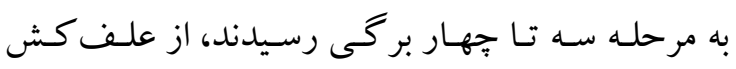

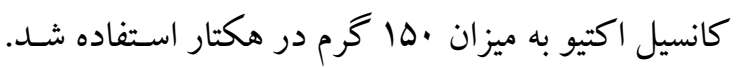

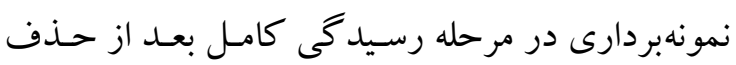

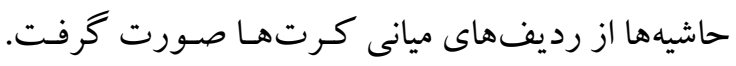
نحوه نمونهبردارى بدين صورت بود كه كليه بوتهــا در

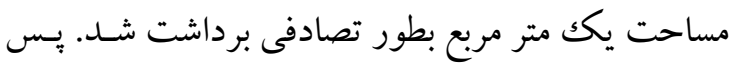

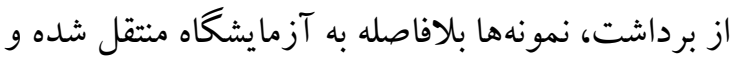

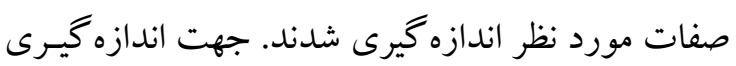
شاخص برداشت، وزن خشك نمونسهــا بطور جداكانهـ

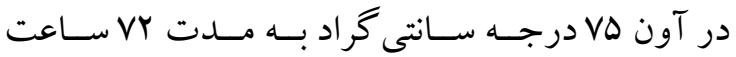

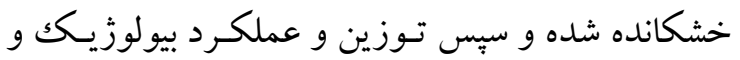

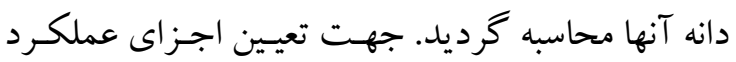

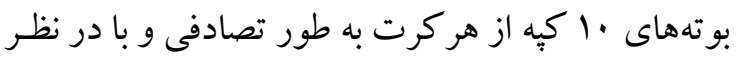

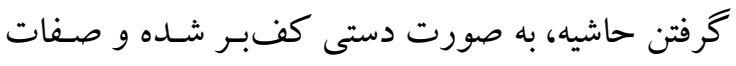

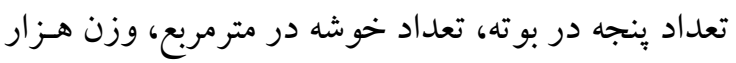

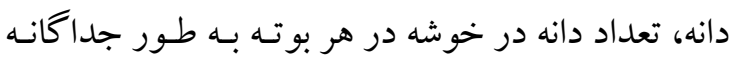

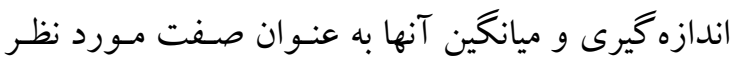

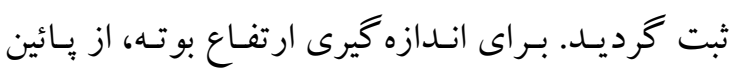

محل اجراى آزمايش در آزمايشگاه بخش آب و خاكك

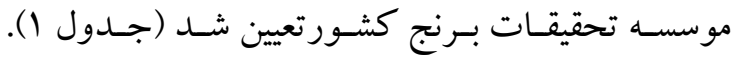

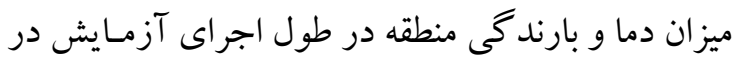

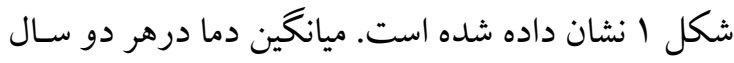

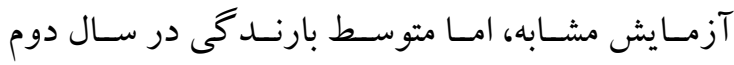

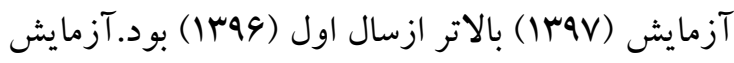
به صورت كرت هاى خرد شد در قالب طرح بلو ككهاى كامل تصادفى با سه تكرار اجرا شد. تيمارهاى آزمايشى

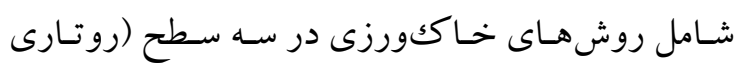
تراكتـورى، خـاككهمـزن مرسـوم تيلـرى و يــادلر دوار

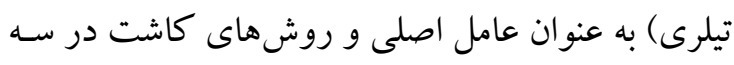

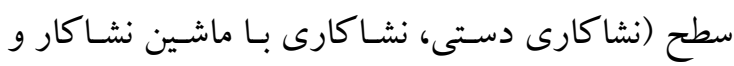

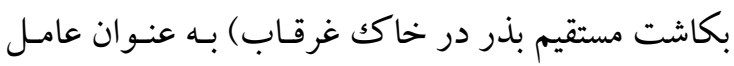

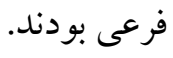

تهيه خزانه براى تيمارهاى نشاكارى دستى و ماشينى

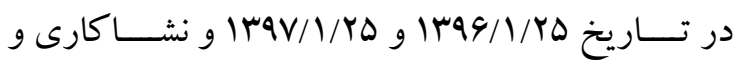
كاشـت مسـتقيم بــذر بــهـ طــور همز مــان در تــاريخ س r/Y

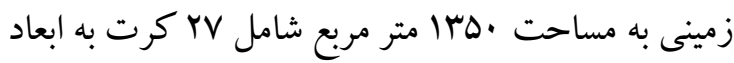
.

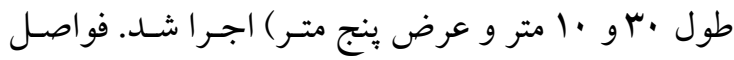

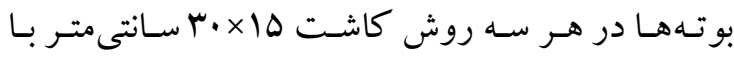

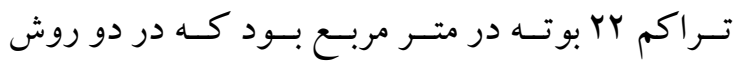

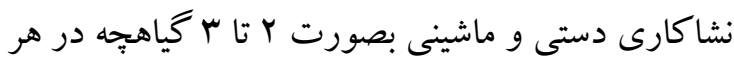

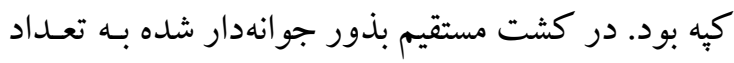

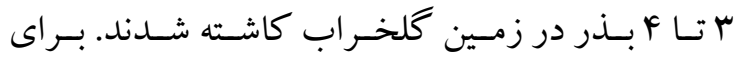

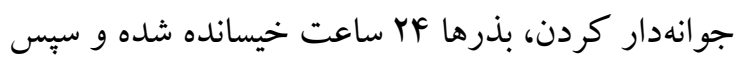

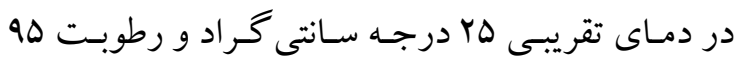

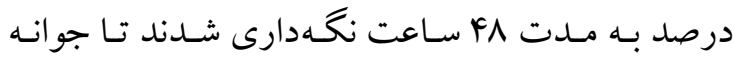

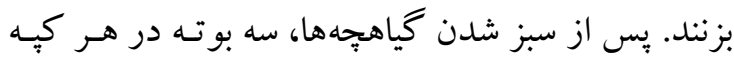

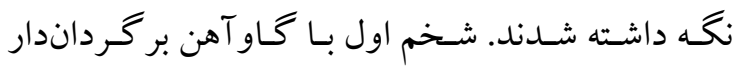

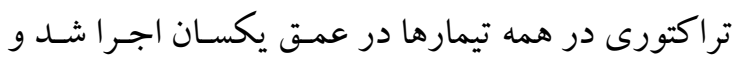

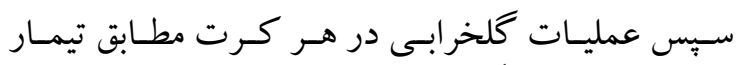

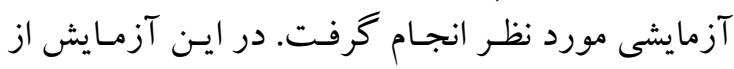


" اثر روشهاى خاككورزى و كاشت.... مينا ابراهيمى و همكاران، 99سا، •499"

برنج سالم (با طول برابـر يـا (Satake TRG 058, Japan)

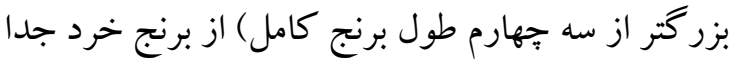
شده و توزين شد. ميزان برنج سالم (درصد)، ميز ان برنج

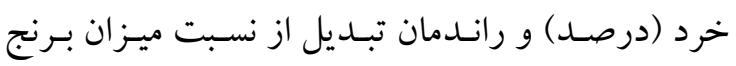

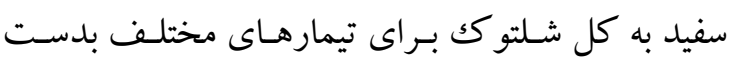

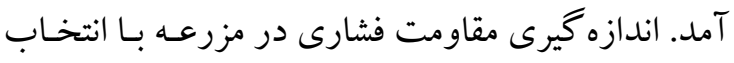

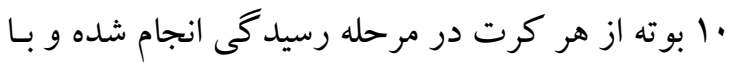

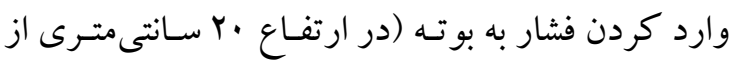

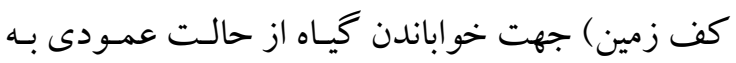

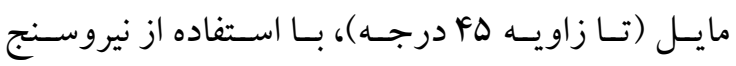

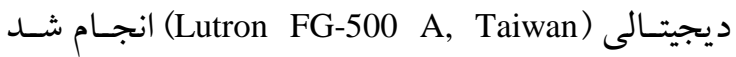

.(Kashiwagi and Ishimaru, 2004)
طوقـه تـا نـو كك سـاقه اصـلى در ·ل بوتـهـ بـا اسـتفاده از

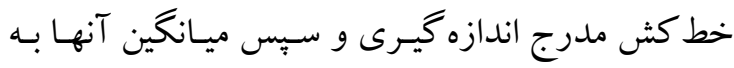

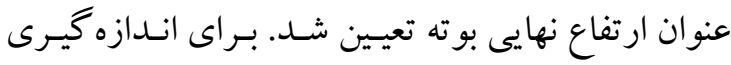

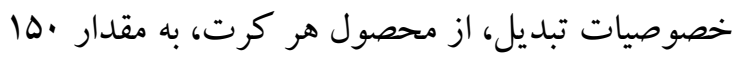

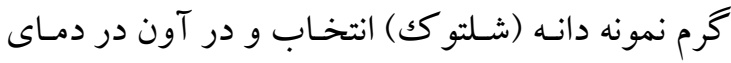

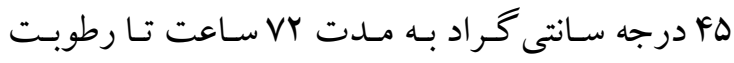

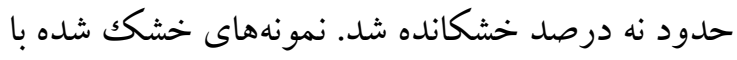

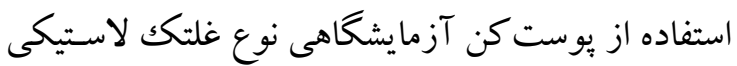
بوسـت كيـرى و (Satake Eng. Co. Ltd., Japan)

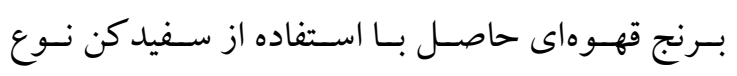

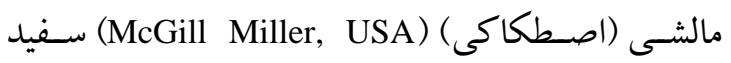

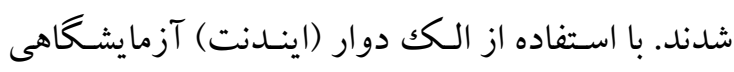

جدول ا-ويز گىهاى فيزيكى و شيميايى خاكك محل اجراى آزمايش

Table 1. Physical and chemical properties of the soil in experiment site

\begin{tabular}{|c|c|c|c|c|c|c|c|}
\hline $\begin{array}{l}\text { بافت خاكك } \\
\text { Texture }\end{array}$ & 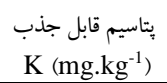 & $\begin{array}{l}\text { فسفر قابل جذب } \\
\text { P (mg.kg }\end{array}$ & $\begin{array}{l}\text { نيتروزٔن كل } 1 \% \text { (\%) }\end{array}$ & $\begin{array}{c}\text { كربن آلى } \\
\text { O.C (\%) }\end{array}$ & SP\% & $\mathrm{pH}$ & $\begin{array}{l}\text { هدايت الكتريكى (dS.m } \\
\text { EC (dS }\end{array}$ \\
\hline رسى-سيلتى Silty Clay & 280 & 7.8 & 0.22 & 2.31 & 74 & 7.34 & 1.85 \\
\hline
\end{tabular}

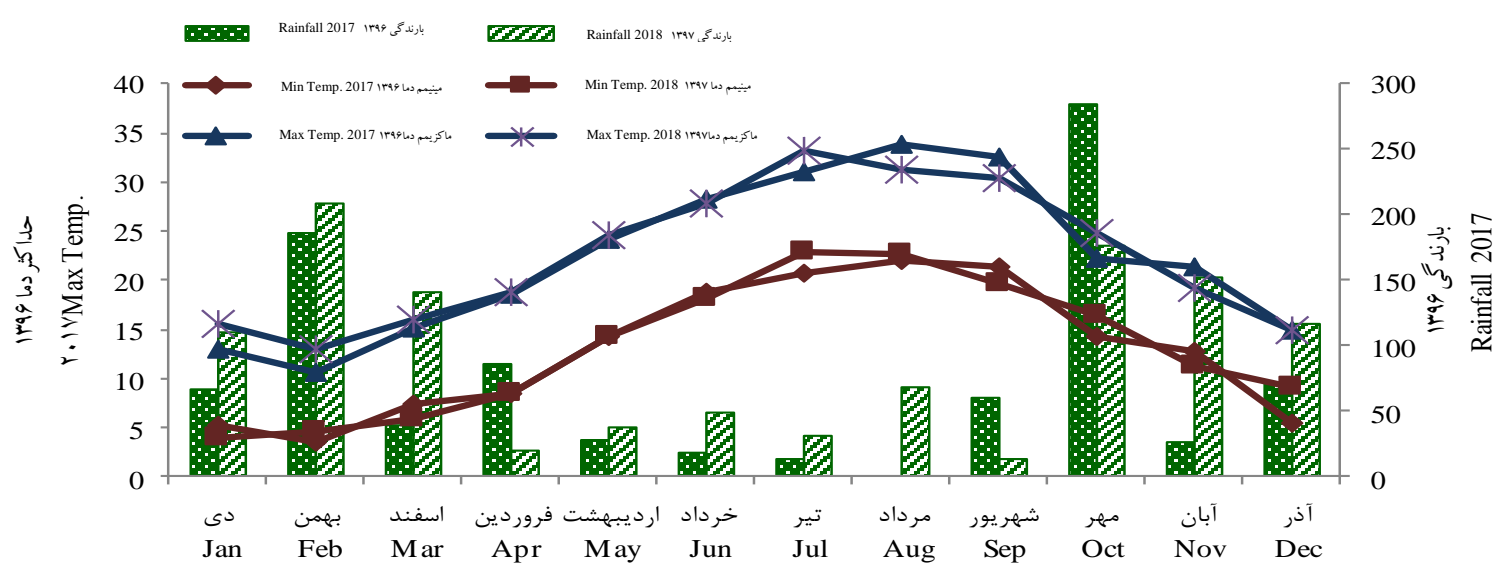

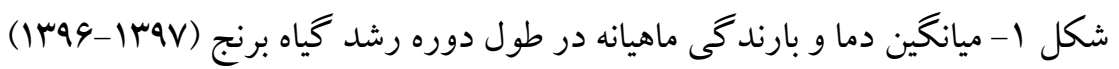

Fig. 1. Monthly mean temperature and rainfall during rice plant growth (2017-2018)

كه بعد از اجراى عمليات كلخر ابى در هر تيمـار بـا رهـا

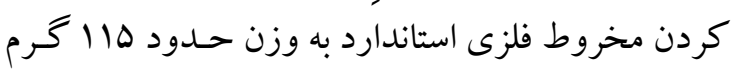

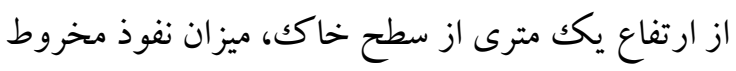

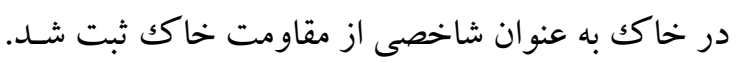

براى تعيسين عمـق نفوذ مخـروط فلزى يـا شـاخص

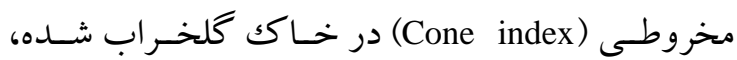
از روش توصسيه شـده سـالوخه و رامالينگَـام (Salokhe) and Ramalingam, 2001) 
خـاككورزى در روش كاشـت بـر عمـق نفـوذ مخـروط سقوطى معنىدار بود. خاككورزى با روتارى تراكتـورى بيشترين عمت نفوذ مخروط سقوطى را داشت و در سـاير روشهاى خاككورزى تفاوت معنى دارى مشـاهده نشــ (شكل r). عمق نفوذ مخروط در يكك خـاكك كلخـراب شده كه به عنوان شاخصى براى مقاومت بـه نفـوذ ريشـه محسوب مسىشـود، بـه عـواملى ماننــ رطوبـت، بافـت و

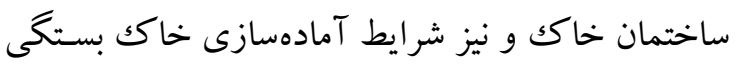
دارد. افزايش شدت و ميزان به هم خـوردكى خـاكك در شرايط استفاده از ادوات تراكتورى، باعـث يـايين رفـتن عمـق لايسه ســت و نفـوذ بيشـتر مخــروط در خــاك كلخر اب مىشود (Alizadeh, 2015).

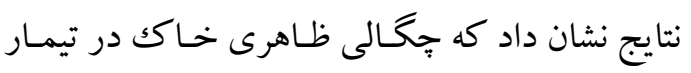

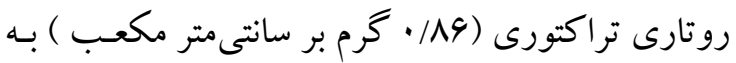
طـور معنسى دارى كمتـر از دو روش ديخـر خـاككورزى بود (جدول Y). اين موضوع را مىتوان بـه شـدت بيشـتر برخورد تيغههاى روتارى تراكتورى با خاكك نسببت داد

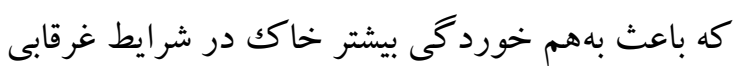

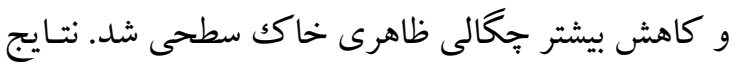
تحقيقات عليز اده (Alizadeh, 2015) نيز روند مشابهى را نشان داد. نتايج تجزيه واريـانس مركـب دادههـا نشـان داد كـه روشهاى خـاككورزى اثـر معنسىدارى بـر ويز كى هـاى

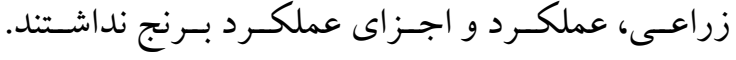
معنى دار نبودن تفـاوت ميـانگين صسفات مـورد بررسىى براى روش هاى مختلف خـاككورزى نشـان دهنــه ايسن

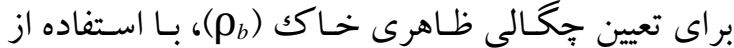
استوانههاى نمونه كيرى كه وزن و حجم آنهـا مشـخص است، نمونههاى دست نخورده يس از عمليات كلخر ابى

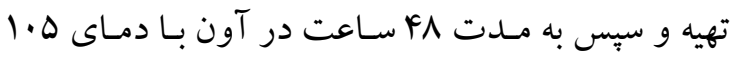

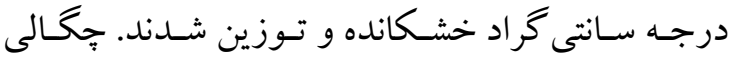
ظاهرى خاكى از رابطه زير به دست آمد:

$\rho_{b=} \mathrm{W}_{\mathrm{s}} / \mathrm{V}_{\mathrm{t}}$

(رابطه (1)

(

مكبc)

=W

= حجم خاكك (سانتى متر مكعب)

قبل از تجزيه مركـب دادههـا، بـه منظور اطمينـان از

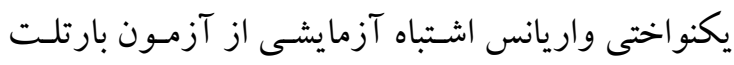
اسـتفاده شـــ. تجزيـه واريـانس و محاسـبات آمـارى بـا

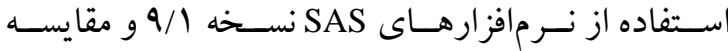
ميانگين ها با استفاده از آزمـون جنــد دامنـهاى تـوكى در سطح احتمال ينج درصد انجام شد.

\section{نتايج و بحث}

نتايج تجزيه واريانس مركب نشان داد كه تيمارهـاى خـاككورزى اثــ معنسى دارى بـر عمـق نفـوذ مخــروط سقوطى و جِّالى ظاهرى خاكك داشتند. بر اساس نتـايج

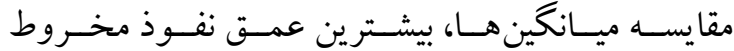
در خاككورزى با روتارى تراكتـورى و كمتـرين مقـدار آن در خاككهمزن مرسـوم تيلـرى (بـه ترتيسب 9ه/ • ا و 9/9 سانتى متر ) مشـاهده شـد (جـدول Y). بـرهمكنش

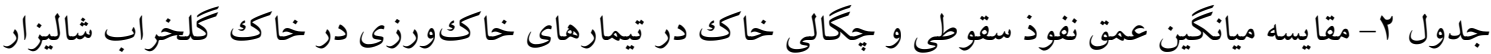

Table 2. Mean comparison of penetrating depth of falling cone and bulk density in tillage treatments in puddled soil

\begin{tabular}{|c|c|c|c|}
\hline Treatments & تيمارهاى آزمايشى & $\begin{array}{c}\qquad \text { نفوذ مخروط سقوطى } \\
\text { Penetrating depth of falling cone (cm) }\end{array}$ & 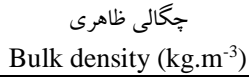 \\
\hline Rotary tractor & روتارى تراكتورى & $10.86 \mathrm{a}$ & $0.86 \mathrm{~b}$ \\
\hline Power tiller rotary puddler & بِادلر دوار تيلرى & $9.15 b$ & $0.96 \mathrm{a}$ \\
\hline Power tiller conventional puddler & خاككهمزن مرسوم تيلرى & $9.09 \mathrm{~b}$ & $0.95 \mathrm{a}$ \\
\hline
\end{tabular}


" اثر روش هاى خاككورزى و كاشت...، مينا ابراهيمى و همكاران، 99با، .199"

.(Parameswari et al., 2014)

بين روشهاى كاشت و اسـتقرار بوتـه از نظر تعـداد ينجه در واحد سطح تفاوت معنى دارى در سطح احتمال يكك درصد مشاهده شد. بيشترين تعـداد ينجسه در واحـد سطح (MFF ينجه در مترمربع) مربوط به كاشـت مسـتقيم

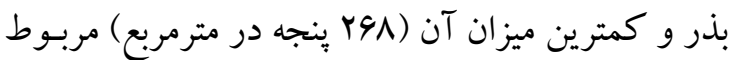
به نشاكارى دستى بود (جدول ب). به نظـر مسىرسـد كـه

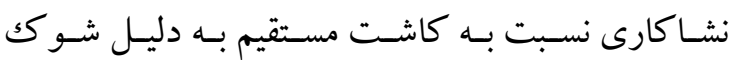
نشاكارى، به زمان بيشترى بـراى تكميـل بنجسهزنسى نيـاز داشته كه مسى توانــ در افزايش تعـداد ينجـه در شـرايط

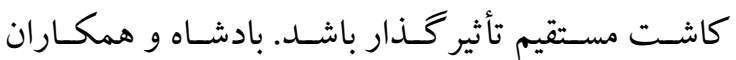
(Badshah et al., 2014) روش كاشت مستقيم در مرحله رسيدگى، صرف نظر از

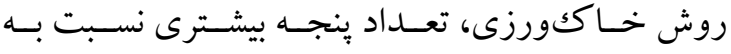
نشاكارى (Yr درصد) به دليل تعداد بوته بالاتر در واحد سطح، توليد شد. با توجه بـه معنسى دار بـودن بـرهمكنش روش كاشت در سـال و تجزيسه جداكانسه دو سـال، بـين روشهاى كاشت و استقرار بوته از نظـر تعـداد ينجـه در واحد سطح اختلاف معنىدارى (در سطح احتمـال يـك درصد) مشاهده شد. بيشترين تعداد ينجه در واحد سطح در هر دو سال آزمـايش (بـهترتيب VYM و سوس بنجـه در مترمربع) مربوط به كاشت مستقيم بذر و كمترين مقـدار آن مربوط به نشاكارى دستى بود. (جدول F). بر اسـاس نتايج بلدست آمـده، حـداكثر تعـداد ينجـه در نشـاكارى ماشينى و دستى يايين تر بود و تعـداد خوشـه در مترمربـع نيز با حداكثر تعداد بنجـه و نـه ميـزان بنجـهـهـاى بـارور ارتباط مثبت داشت. اين موضوع با يافته هـاى هوانـگ و همكـاران (Huang et al., 2015) مطابقـت دارد، البتـهـ ينجهازنى بيش از حـد ممكـن اسـت باعـث عـدم تكامـل اكثر ينجهها، دانهبندى ضعيف، اندازه كو جِك خوشهـ و

كاهش عملكرد دانه شود (Badshah et al, 2014). نتايج تجزيه واريـانس مركـب دادههـا نشـان داد كـهـ روش هاى خاككورزى و كاشت و بـرهمكنش آنها اثر معنى دارى بر تعداد دانـه در خوشـه نداشـتند. ايسن نتـايج
است كه كليه روشهاى خاككورزى بستر مناسبى بـراى

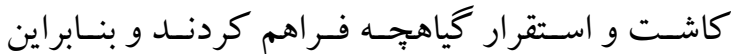
مى تواند جايخزين يكديخر باشند. در اين صورت معيار

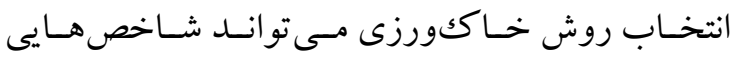

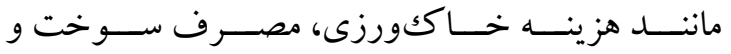

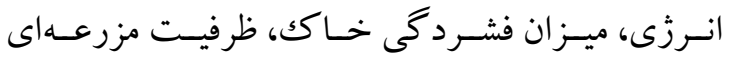
و نــوع ماشـينهــا و ادوات در دسـترس باشــد. نتــايج

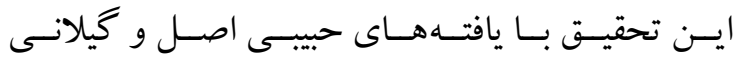
مطابقـــت دارد. (Habibi-Asl and Gilani, 2014) خسـروانى و همكــاران (Khosravani et al., 2003 (

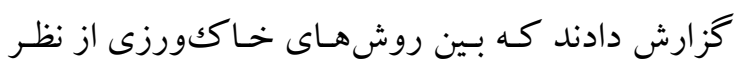
عملكرد دانه، تعداد دانه در سنبله و وزن هزار دانه گنـدم تفاوت معنى دارى وجود نداشت. نتايج نشان داد كه بسين روش هـاى كاشـت از نظـر ارتفـاع بوتهه، تعـداد ينجسه و خوشـه در واحسـ سـطح، شـاخص برداشـت و مقاومست فشارى تفاوت معنىدارى وجود داشت. بيشترين ارتفـاع بوته (FF ا سـانتى متـر) در تيمـار كاشـت مستقيم بــر و كمترين مقدار (ITV سانتىمتر) در تيمار نشاكارى دستى بدسـت آمسـ (جـدول س). بـا توجسه بـه معنسىدار بـودن برهمكنش روش كاشت در سـال و تجزيسه جداكانسه دو سال، تيمارهـاى روش كاشت در سـال 9 9با در سـطح

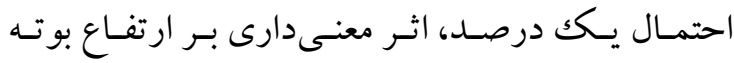
داشتند. بيشترين ارتفاع بوته ( •إ سانتىمتر) در كاشـت مستقيم بـــر و كمتـرين مقــدار آن ( اFI سـانتىمتـر) در تيمار نشاكارى دستى بدست آمد، اما در سال IMaV اثـر اين تيمارها بـر ارتفـاع بوتـه معنسىدار نبـود (جــدول F). ارتفــاع بوتسه از صـفات كيـاهى اسـت كـه تحست تـأثير زنتيكك، مديريت زراعى، شـرايط رشـد، سـن كياهُجـه، قدرت رويش و تغذيه قرار مى گيرد. به نظر مىرسد كـه در تيمـار كاشـت مسـتقيم بـذر بوتـههـا بـه دليـل تــراكم

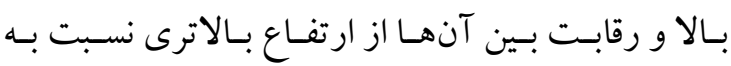
نشاكارى برخوردار بودند. اين موضوع ممكـن اسـت بـه

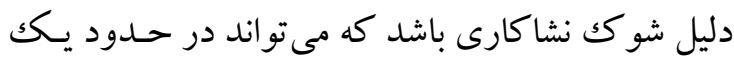

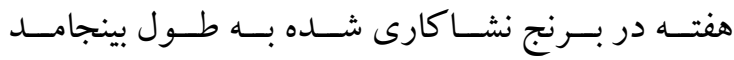


جدول r- مقايسه ميانگين عملكرد دانه و اجزاى عملكرد برنج رقم هاشمى در تيمارهاى روشهاى كاشت

Table 3. Mean comparison of grain yield and yield component of rice (cv. Hashemi) in planting treatments

\begin{tabular}{|c|c|c|c|c|c|c|c|c|c|c|}
\hline Treatments & تيمارهاى آزمايشى & $\begin{array}{c}\text { Plant height } \\
\text { (cm) }\end{array}$ & $\begin{array}{l}\text { ينجه در مترمربع.m } \\
\text { No. tiller.m }\end{array}$ & $\begin{array}{c}\text { دانه در خوشه } \\
\text { No. grain. panicle }{ }^{-1} \\
\end{array}$ & $\begin{array}{c}\text { خوشه در مترمربع. } \\
\text { No. Panicle. m². }\end{array}$ & $\begin{array}{c}\text { وزن هزار دانه } \\
1000 \text { grain weight } \\
\text { (g) }\end{array}$ & $\begin{array}{c}\text { عملكرد دانه } \\
\text { Grain yield } \\
\left(\mathrm{kg} \cdot \mathrm{ha}^{-1}\right)\end{array}$ & $\begin{array}{c}\text { عملكرد زيستى } \\
\text { Biological yield } \\
\left(\mathrm{kg} \cdot \mathrm{ha}^{-1}\right)\end{array}$ & $\begin{array}{c}\text { شاخص برداشت } \\
\text { Harvest index } \\
\text { (\%) }\end{array}$ & $\begin{array}{c}\text { مقاومت فشارى } \\
\text { Pushing resistance } \\
\text { (N) }\end{array}$ \\
\hline Manual transplanting & نشاكارى دستى & $137 b$ & $268 \mathrm{c}$ & $90 \mathrm{a}$ & $261 b$ & $24.3 \mathrm{a}$ & $4394 a$ & 9216a & $47.1 \mathrm{~b}$ & $5.52 \mathrm{ab}$ \\
\hline Mechanized transplanting & نشاكارى ماشينى & $141 \mathrm{a}$ & $298 \mathrm{~b}$ & $92 \mathrm{a}$ & 284ab & $24.4 \mathrm{a}$ & $4618 \mathrm{a}$ & $9341 \mathrm{a}$ & $49.2 \mathrm{a}$ & $5.73 \mathrm{a}$ \\
\hline Direct seeding & كاشت مستقيم بذر & $144 \mathrm{a}$ & $344 \mathrm{a}$ & $95 \mathrm{a}$ & $287 \mathrm{a}$ & $24.5 \mathrm{a}$ & $4577 \mathrm{a}$ & $9617 \mathrm{a}$ & $47.5 \mathrm{ab}$ & $5.19 b$ \\
\hline
\end{tabular}

Means in each column followed by similar letter(s) are not significantly different at 5\% probability level, using Tukey's test

$$
\text { جدول F- مقايسه ميانگين عملكرد و اجزاى عملكرد برنج رقم هاشمى در تيمارهاى روش هاى كاشت ( }
$$

Table 4. Mean comparison of grain yield and yield components of rice (cv. Hashemi) in planting method treatments (2017 and 2018)

\begin{tabular}{|c|c|c|c|c|c|c|c|c|c|c|c|}
\hline & & \multicolumn{2}{|c|}{$\begin{array}{c}\text { ارتفاع بوته } \\
\text { Plant height (cm) }\end{array}$} & \multicolumn{2}{|c|}{$\begin{array}{l}\text { ينجه در مترمربع. } \\
\text { No. tiller.m-2 }\end{array}$} & \multicolumn{2}{|c|}{$\begin{array}{c}\text { دانه در خوشه } 2 \text { مo. grain. panicle-1 } \\
\text { No. }\end{array}$} & \multicolumn{2}{|c|}{$\begin{array}{c}\text { عملكرد دانه } \\
\text { Grain yield }\left(\mathrm{kg} \cdot \mathrm{ha}^{-1}\right)\end{array}$} & \multicolumn{2}{|c|}{$\begin{array}{c}\text { عملكرد زيستى } \\
\text { Biological yield }\left(\mathrm{kg}^{2} \mathrm{ha}^{-1}\right)\end{array}$} \\
\hline & & 1799 & IrqV & 1799 & irqv & 1799 & Irav & $1 \% 99$ & IrqV & 1149 & IrqV \\
\hline Treatment & تيمارهاى آزمايشى & 2017 & 2018 & 2017 & 2018 & 2017 & 2018 & 2017 & 2018 & 2017 & 2018 \\
\hline Manual transplanting & نشاكارى دستى & $141 \mathrm{c}$ & $133 \mathrm{a}$ & $276 b$ & $259 b$ & $93 a$ & $88 \mathrm{ab}$ & $4738 \mathrm{a}$ & $4050 \mathrm{~b}$ & $10505 \mathrm{a}$ & $7928 b$ \\
\hline Mechanized transplanting & نشاكارى ماشينى & $145 \mathrm{ab}$ & $137 \mathrm{a}$ & $308 \mathrm{ab}$ & $289 b$ & $96 a$ & $90 \mathrm{a}$ & $4951 \mathrm{a}$ & $4285 \mathrm{ab}$ & $10576 \mathrm{a}$ & $8107 b$ \\
\hline Direct Seeding & كاشت مستقيم بذر & $150 \mathrm{a}$ & $137 \mathrm{a}$ & $326 a$ & $363 \mathrm{a}$ & $99 \mathrm{a}$ & $81 \mathrm{~b}$ & $4473 a$ & $4681 \mathrm{a}$ & $10148 \mathrm{a}$ & $9086 a$ \\
\hline
\end{tabular}

Means in each column, followed by similar letter(s) are not significantly different at 5\% probability level, using Tukey's test 
خـاكك همـزن مرسـوم تيلـرى و بـادلر دوار تيلــى و در

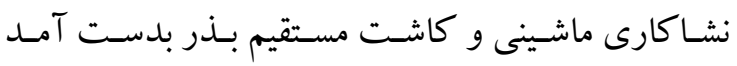
(شكل Y). به نظرمىرسد كه خاكك همزنهاى تيلـرى بـاس

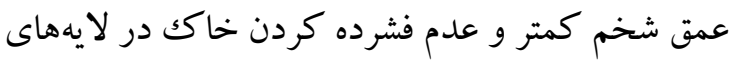

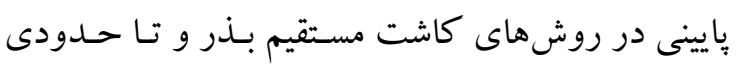

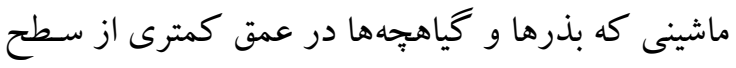

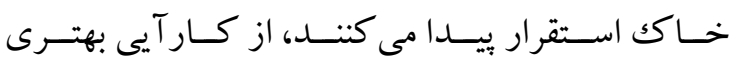
برخوردار هسـتند و ايـن موضـوع باعـث افزايش تعـداد

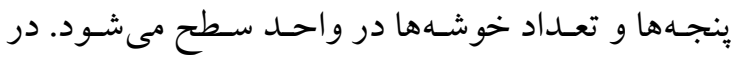
واقع فر اهم بـودن فضـاى مناسـب بـراى رشـــ بوتـهـــا، برهمكنش مثبت اين عوامل بوده است. ليـو و همكـاران

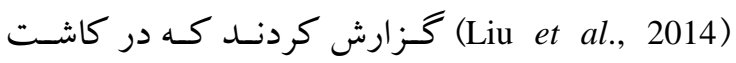
مستقيم بذر بـرنج در مقايسـه بـا روش نشـاكارى، تعـداد

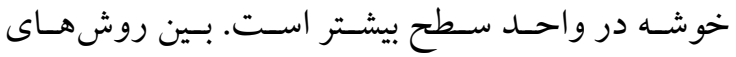

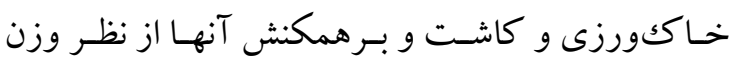
هزار دانه تفاوت معنىدارى مشاهده نشد. در برنج اغلب

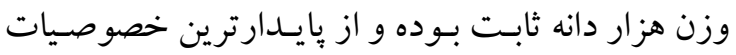

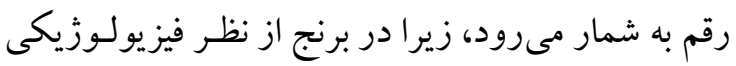
رشد دانه توسط يوسته دانه (لما و بالئا) محدود مسى شـود (Gholami Rezvani et al., 2015) است كه اثر روشهاى خاككورزى بـر صـفاتى از قبيل

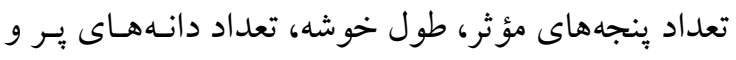
خوشهجه بارور در برنج معنسى ار اسـت، امـا وزن هـزار

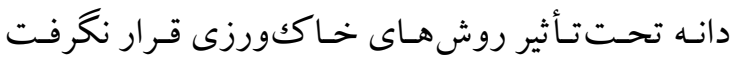

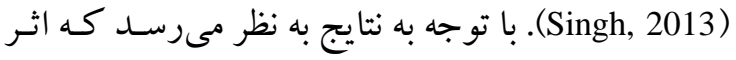
شرايط محيطى بر وزن هزار دانه ناجيز است. نتايج تجزيه واريانس مر كب دادهها نشان داد كه بين

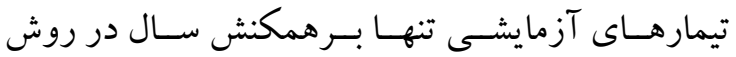

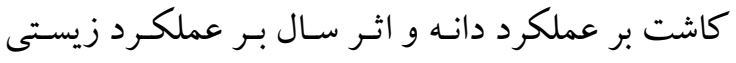

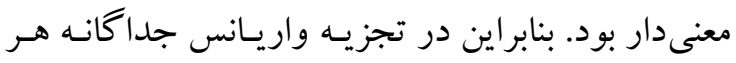

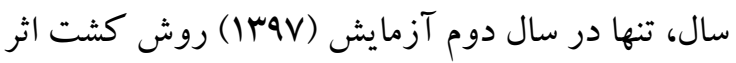

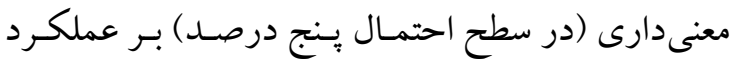
دانه و عملكرد زيستى داشت. نتـايج مقايسه ميـانكين هـا

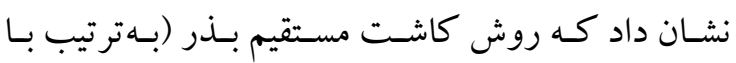

نشان مىدهد كه كليه روشهاى خـاككورزى و كاشـت

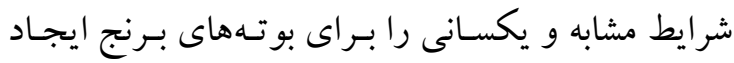

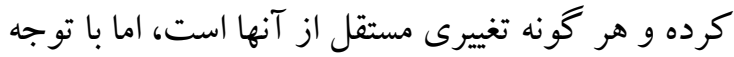

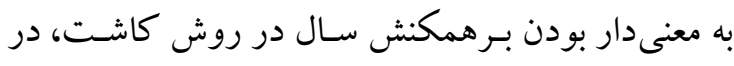
تجزيه واريانس جداكانه هر سال، روش كاشت بـه طور

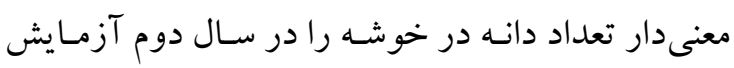
(IrqV)

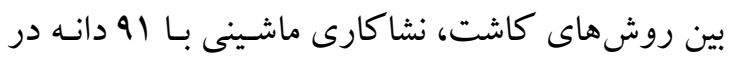

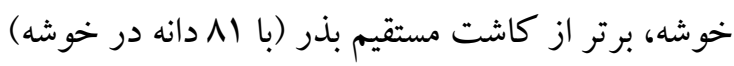

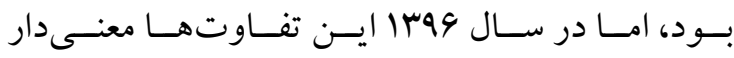
نبود (جدول F). به نظر مىرسد كـه كمتـر بـودن تعـداد دانه در خوشه در روش كاشت مستقيم مربوط بـه تعـداد

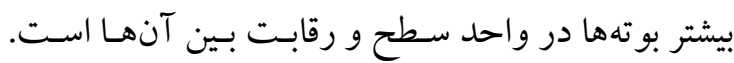

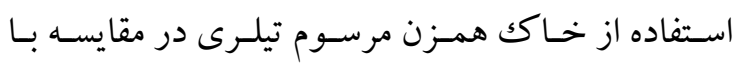

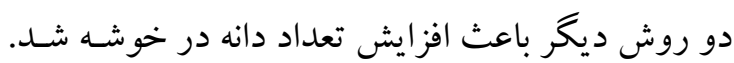

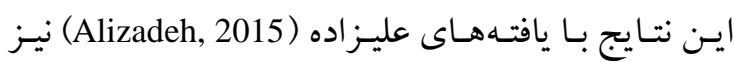

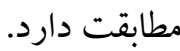

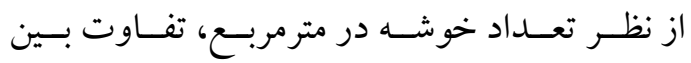

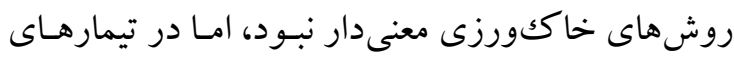
روش كاشت، تفاوت معنىدارى در سـطح احتمـال يـنج درصد از نظر تعداد خوشه در واحد سطح وجود داشت.

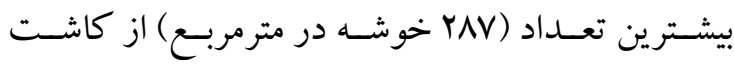
مستقيم بذر و كمترين تعداد ( اצY خوشه در مترمربع) از

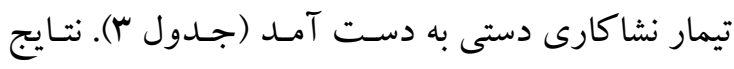

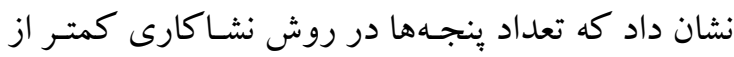
كاشت مستقيم بذر بوده كه مى توانــ دليـل بيشـتر بـودن

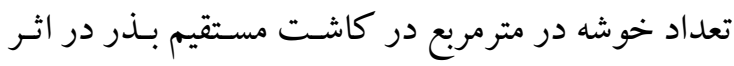

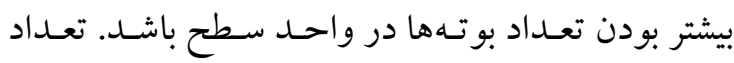
خوشه بيشتر در واحد سطح در كاشـت مستقيم بـــر بـهـ

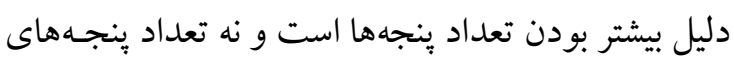
بارور كـه بـه خوشـه مسىرونسـ (Badshah et al, 2014).

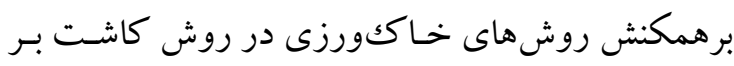
تعداد خوشه در واحد سطح معنىدار بود. بيشترين تعداد خوشـه در واحسـ سـطح در روشهــاى خـاككورزى بـا 
نشاكارى برنج گزارش كردند كه عملكرد دانه در دو

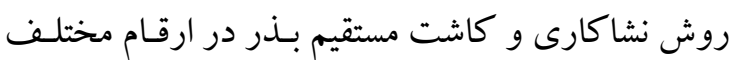
مشابه بوده و عملكرد دانه در كاشت مستقيم بذر عمـدتا

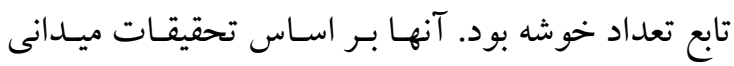

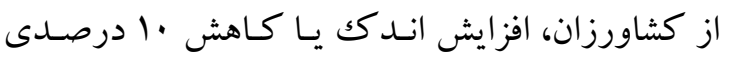
در عملكرد دانه را در كاشـت مستقيم بـــر در مقايسـهـ

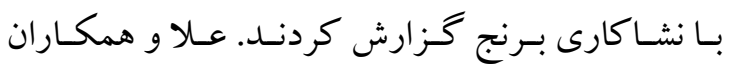
نيز گز ارش كردند عملكرد دانه برنج (Ala et al., 2014)

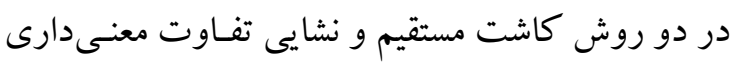

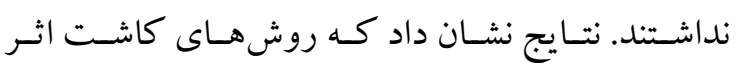

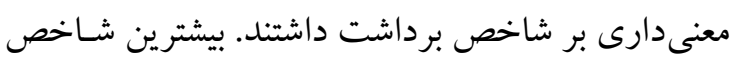

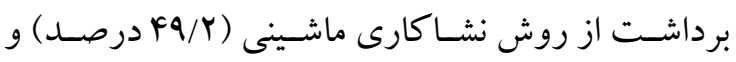

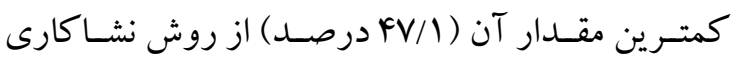

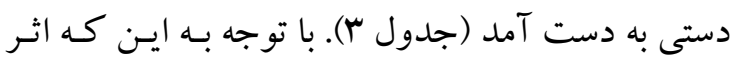

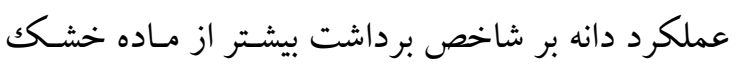

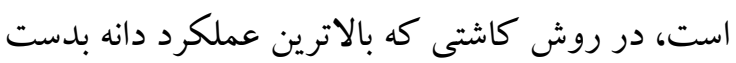
آمد، بالاترين شاخص برداشت نيز حون حاصل شد. روشهاى خـاككورزى، كاشـت و بـرهمكنش آنها

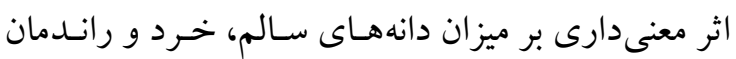
تبديل نداشتند. راندمان تبديل، ميز ان برنج سـالم و بـرنج

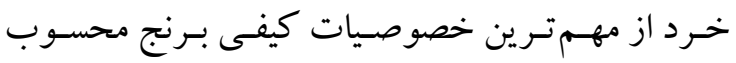

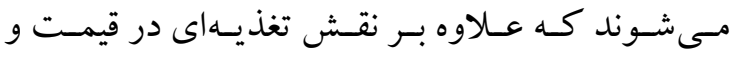
بازاريسندى محصول برنج نقش به سزايى دارند. كيفيت

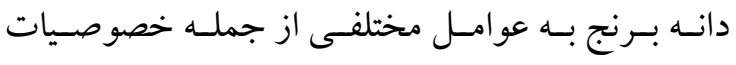
ززنتيكى، شـرايط محيطى و روش كاشـت بسـتخى دارد.

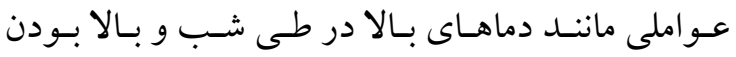

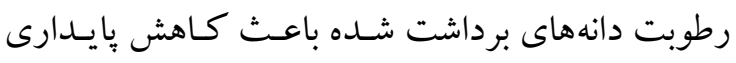

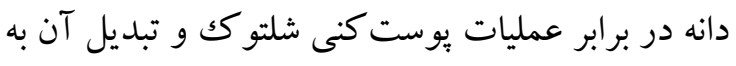

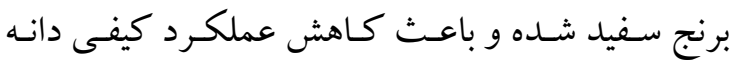
مسىشوند (Gholami Rezvani et al., 2015). نتسايج يُزوهش حاضر نشان داد كه ميزان دانهاى سالم، خرد و

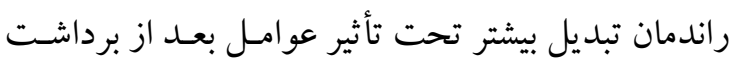

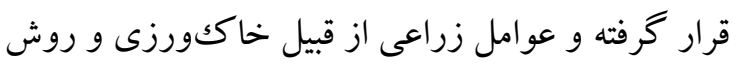
كاشت تأثير جِندانى بر آنها ندارند.

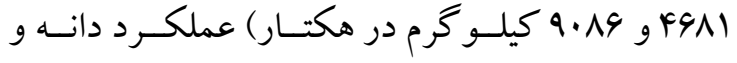
عملكرد زيستى بيشتر و روش نشاكارى دستى (بـهترتيب

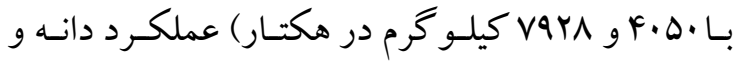

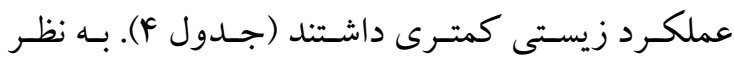

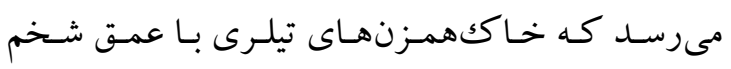

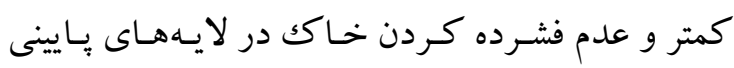

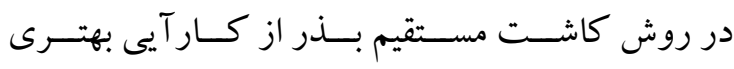

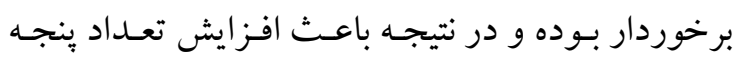

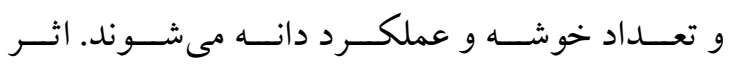

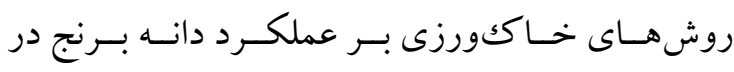

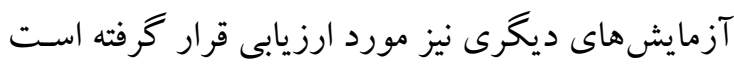
(Wu et al., 2013; Huang et al., 2015) همكاران (Amato et al., 2013) كزار دادند كه عملكرد دانه گندم در روش هـاى خـاككورزى متـداول بيشـتر از روش هاى كاهش يافته و بدون خاككورزى بود. عليز اده در ارزيــابى اثــــ روش و دفعـات (Alizadeh, 2015)

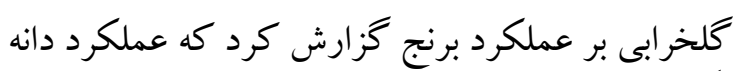

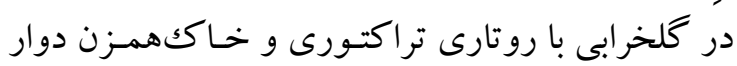

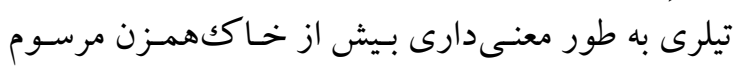
تيلرى و يادلر مخروطى تيلرى بـود كـه بـر اسـاس نتسايج

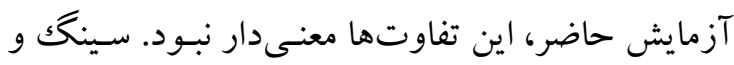

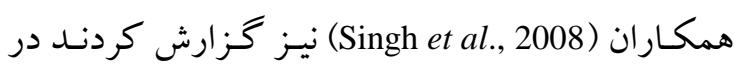

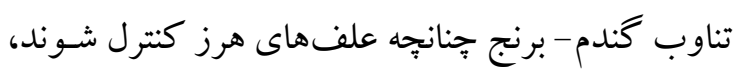

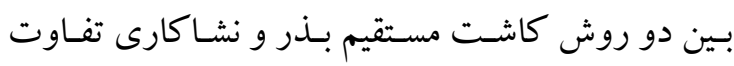

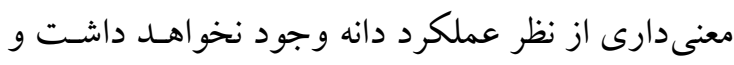

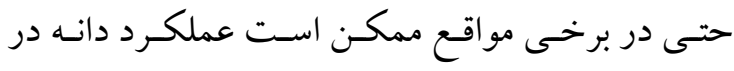
كاشـت مستقيم بيشـتر باشــ (Bhushan et al., 2007).

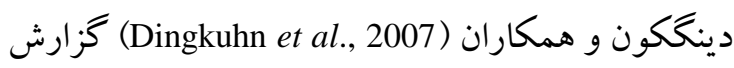
نمودند كه كاشت مستقيم بذر برنج باعث افزايش تعداد ينجه و عملكرد دانه مىشود. محققان مناطق مختلف دنيا

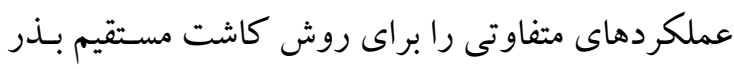

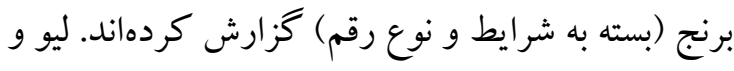

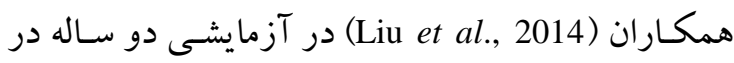

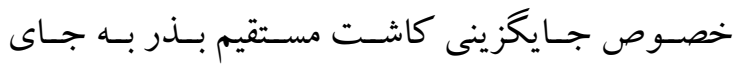


" اثر روش هاى خاككورزى و كاشت...، مينا ابراهيمى و همكاران، 99 1، .199"

كه ساقه تا جهه حد نيرو را مسىتوانـد تـا قبـل از شكسـتن تحمل كند و يّ از آن قابليت بر گشتن مجدد به حالـت قائم را دارد. بر اساس نتايج كاشت مستقيم بذر كمتـرين مقاومست فشـارى را دارا بـود كـهـ مسى توانــد بـه دليـل كاشت سطحى تر بذر و عدم كسـترش عميـق ريشـههاى

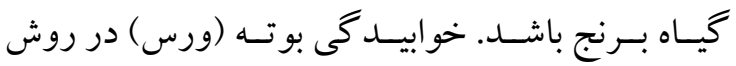

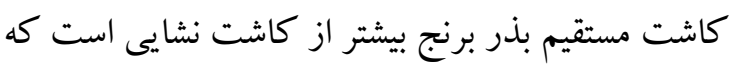

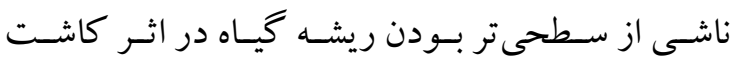

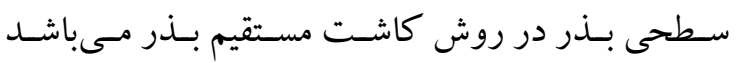

.(Akhgari et al., 2017)

$$
\begin{aligned}
& \text { نتـايج تجزيسه واريـانس دادههـا نشـان داد كـهـ بـين } \\
& \text { روشهـاى خـاككورزى از نظـر مقاومست فشـارى بوتـهـ }
\end{aligned}
$$

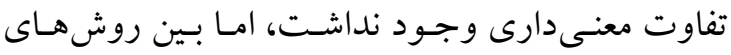

$$
\begin{aligned}
& \text { كاشــت از نظـر مقاومست فشـارى بوتـه تفــاوت كــاملا }
\end{aligned}
$$

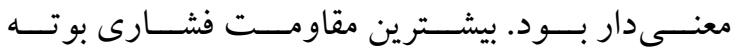

$$
\begin{aligned}
& \text { (ه/MT (مربوط به روش نشاكارى ماشـينى بـوده و }
\end{aligned}
$$

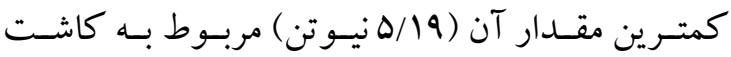

$$
\begin{aligned}
& \text { مستقيم بذر بود (جدول ץ). مقاومت فشارى نشان دهنده } \\
& \text { ايستادكى بخش هاى يايينى بوته در برابر فشـارهاى وارد } \\
& \text { شده بر اين بخش است. مقاومت فشارى نشـان مسىدهــ }
\end{aligned}
$$

"Rotary tractor روتارى تراكتورى

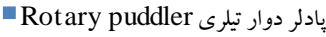

خاك همزن مرسوم تيلرى Conventional tiller

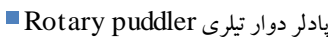

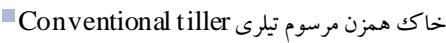
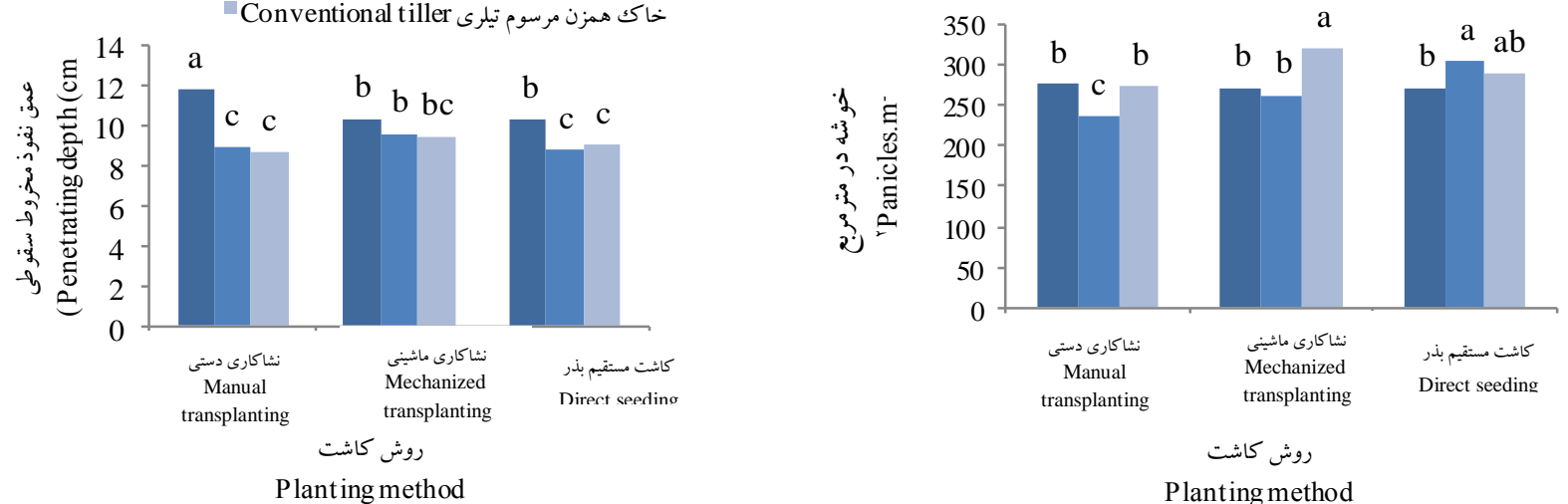

Planting method

شكل r- برهمكنش روش هاى خاككورزى و كاشت بر تعداد خوشه در واحد سطح و عمق نفوذ مخروط

$$
\text { سقوطى برنج رقم هاشمى }
$$

Fig. 2. Interaction effect of tillage and planting methods on No. panicles. $\mathrm{m}^{-2}$ and penetrating depth of falling cone

ميانكين صفات گيـاهى مـورد ارزيـابى بـر اى روش هـاى

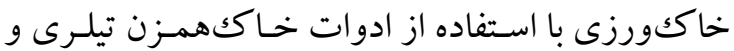

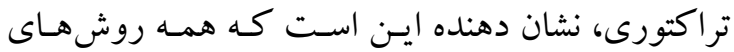
خـاككورزى بسـتر مناســى بـــراى كاشـت و اسـتقر ار كياهجه هاى بـرنج ايجـاد كرده و مسىتوانـــ جـايخزين

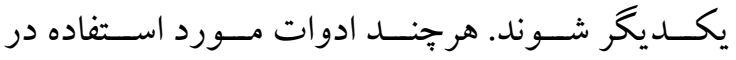
تيمارهاى خاككورزى اثـر قابـل تـوجهى بـر عملكـرد و اجزاى عملكرد برنج نداشتند، با اين حال اجراى بيش از حـد و غيرضـرورى عمليـات خـاككورزى و ادواتسى بـا

\section{نتيجه كيرى}

نتــايج حاصــل از ايسـن يــزوهش نشـــان داد كـــه خـاككورزى اثـر معنسىدارى بـر عمـق نفـوذ مخــروط

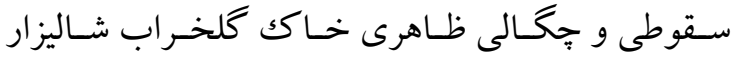
داشت و بيشترين عمق نفوذ مخروط سـقوطى بـه عنـوان شاخصـى در ميـزان نفــوذ ريشـه، در خــاككورزى بــا روتارى تراكتورى بدست آمد، اما در ساير ويز كىهـاى

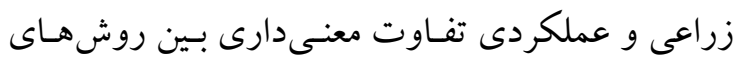

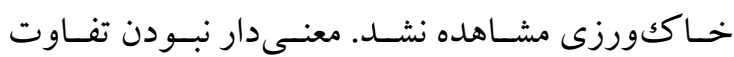




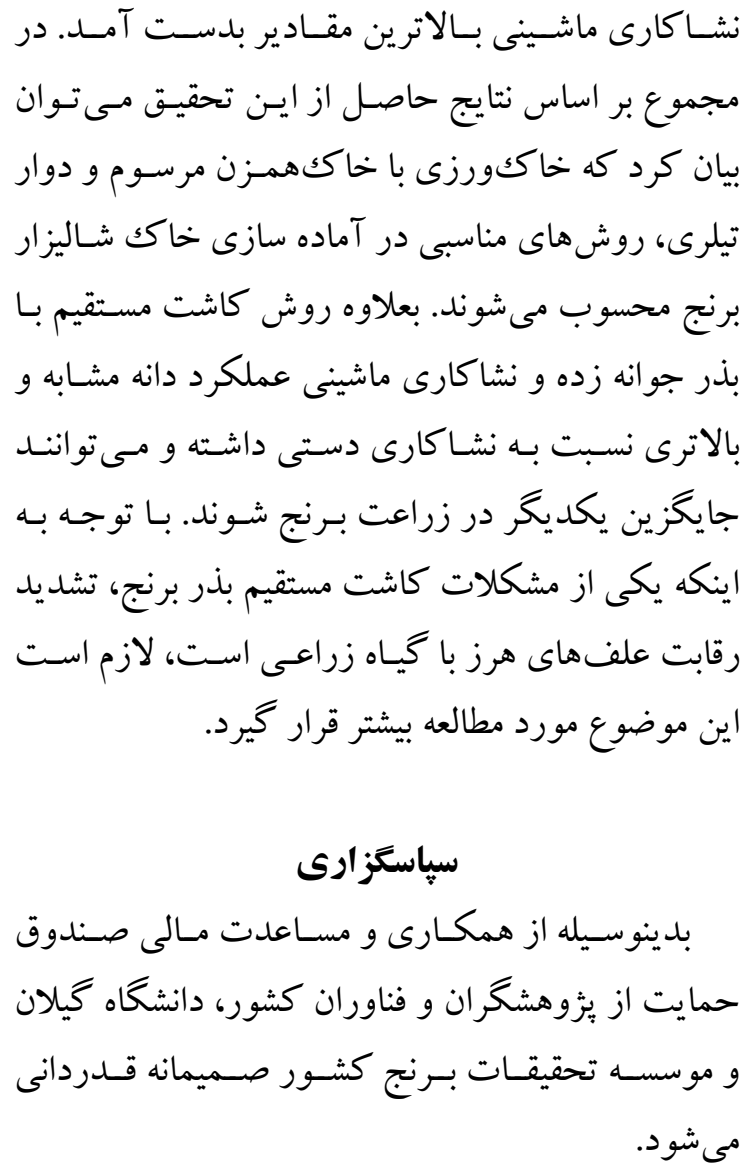

\section{References}

Akhgari, H., M. Esfahani, G. Mohsenabadi and A. Alami. 2017. Effect of seed priming on lodging indices of rice (Oryza sativa L.) cultivars in direct seeding method. J. Crop Prod. Proc. 7(3): 129-143. (In Persian with English abstract).

Ala, A., M. Aghaalikhani, B. Amiri Larijani and S. Soufizadeh. 2014. Comparison of direct sowing system and planting of rice in Mazandaran province: weed competition, yield and yield components. Iran J. Crop Res. 12(3): 463-475. (In Persian with English abstract).

Ali, A. M., H. S. Thind, S. Sharma and S.Y. Singh. 2015. Site-specific nitrogen management in dry directseeded rice using chlorophyll meter and leaf colourchart. J. Pedosphere. 25: 72-81.

Alizadeh, M. R. 2015. Effect of method and times of puddling on some soil physical properties and rice grain yield. Cereal Res. 5(1): 33-43. (In Persian with English abstract).

Amato, G., P. Ruisi, A. S. Frenda, G. Di Miceli, S. Saia, A. Plaia and D. Giambalvo. 2013. Long-term tillage and crop sequence effects on wheat grain yield and quality. Agron. J. 105(5): 1317-1327 .

Badshah, M., T. Naimei, Y. Zou, M. Ibrahim and K. Wang. 2014. Yield and tillering response of super hybrid rice Liangyoupeijiu to tillage and establishment methods. The Crop J. 2(1): 79-86. 


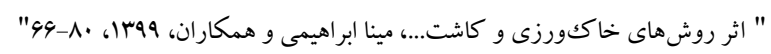

Bhushan, L., J. K. Ladha, R. K. Gupta, S. Singh, A. Tirol-Padre, Y. S. Saharawat, M. Gathala, and H. Pathak. 2007. Saving of water and labor in rice-wheat system with no-tillage and direct seeding technologies. Agron. J. 99: 1288-1296.

Chen, S., Q. Ge, G. Chu, C. Xu, J. Yan and X. Zhang. 2017. Seasonal differences in the rice grain yield and nitrogen use efficiency response to seedling establishment methods in the middle and lower reaches of the Yangtze River in China. Field Crops Res. 205: 157-169.

Dingkuhn, M., H. F. Schnier, S.K. Datta, E. Wijangkco and K. Dorffling. 2007. Diurnal and developmental changes in canopy gas exchange in relation to growth in transplanted and direct seeded flooded rice. Aust. J. Crop Sci. 17(2): 119-134.

Farooq, M., K. H. M. Siddique, H. Rehman, T. Aziz, D. J. Lee and A. Wahid. 2011. Rice direct seeding: experiences, challenges and opportunities. Soil Tillage Res. 111: 87-98.

Gangwar, K. S., M. S. Gill, O. K. Tomar and D. K. Pandey. 2008. Effect of crop establishment methods on growth, productivity and soil fertility of rice (Oryza sativa) - based cropping systems. Indian J. Agron. 53(2): 102-106.

Gholami Rezvani, N. M. Esfahani, Sh. Kabi Rahnema, A. Alami and M. Nahvi. 2015. Effect of seed rate on grain yield and yield components of rice (cv. Hashemi) in direct seeding methods. Seed Plant Prod. J. 31-2: 37-56. (In Persian with English abstract).

Habibi-Asl, J. and A. A. Gilani. 2014. Effect of tillage method and rice cultivation on machine parameters, yield and yield components of wheat and residue management for rice-wheat rotation in Khuzestan. J. Agric. Engin. Res. 15(2): 45-62. (In Persian with English abstract).

Horgan, F. G., J. Y. Figueroa and M. L. P. Almazan. 2014. Seedling broadcasting as apotential method to reduce apple snail damage to rice. Crop Prot. 64: 168-176.

Huang, M., X. F. Zhou, F. B. Cao, B. Xia and Y. B. Zou. 2015. No-tillage effect on rice yield in China: a meta-analysis. Field Crops Res. 183: 126-137.

Ivani, A., M. Safari and A. Hedayatipour. 2014. Comparison of direct sowing methods of germinated (machined and manual) rice with transplantation. J. Agric. Machin. 4(1): 108-115. (In Persian with English abstract).

Kashiwagi, T. and K. Ishimaru. 2004. Identification and functional analysis of a locus for improvement of lodging resistance in rice. Plant Physiol. 134(2): 676-683.

Khan N. I., A. U. Malik, F. Umer and M. I. Bodla. 2010. Effect of tillage and farmyard manure on physical properties of soil. Int. Res. J. Plant Sci.1(4): 75-82.

Li, X.C., Q.Y. Zhong, Y.X. Li, G.H. Li, Y.F. Ding, S.H. Wang, Z.H. Liu, S. Tang, C.Q. Ding and L. Chen. 2016. Triacontanol reduces transplanting shock in machine-transplanted rice by improving the growth and antioxidant systems. Front. Plant Sci. 7: 1-10. 


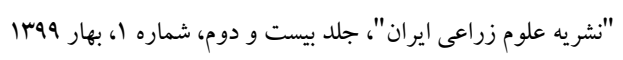

Liu, H., S. Hussain, M. Zheng, Sh. Peng, J. Huang, K. Cui and L. Nie. 2014. Dry direct-seeded rice as an alternative to transplanted-flooded rice in Central China. Agron. Sustain. Dev. 35(1): 285-294.

Parameswari, Y. S., A. Srinivas, T. Ram Prakash and G. Narender. 2014. Effect of different crop establishment methods on rice (Oryza sativa L.) growth and yield- A review. Agric. Rev. 35(1): 74-77.

Khosravani, A., M. Zabolestani, A. Sharifi, A. Mohsenimanesh, M. Sharbanoo Nejad and A. Hemmat. 2003. Evaluation of the possibility of shallow tillage in irrigated wheat. J. Agric. Eng. Res. 17(4): 29-46. (In Persian with English abstract).

Salokhe, V. M. and N. Ramalingam. 2001. Effects of direction of rotation of a rotary tiller on properties of Bangkok clay soil. Soil and Tillage Res. 63: 65-74.

Sangeetha, C. and P. Baskar. 2015. Influence of different crop establishment methods on productivity of riceA Review. Agric. Rev. 36(2): 113-124.

Singh, S., J. K. Ladhab, R. K. Guptaa, L. Bhushana, and A. N. Raob. 2008. Weed management in aerobic rice systems under varying establishment methods. Crop Protec. 27: 660-671.

Singh, Y. 2013. Crop and water productivity as influenced by rice cultivation methods under organic and inorganic sources of nutrient supply. Paddy Water Environ. 11(1-4): 531-542.

Sinha, K. P., B. K. Singh, and M. Kumar. 2008. Effect of seed rate, weed management and establishment methods on irrigated rice in Bihar. Los Baños (Philippines): IRRI and Pantnagar (India): Directorate of Experiment Station, G.B. Pant University of Agriculture and Technology. 272 p.

Wu, W., L. X. Nie, Y. C. Liao, F. Shah, K. H. Cui, Q. Wang, Y. Lian and J. L. Huang. 2013. Toward yield improvement of early-season rice: other options under doublerice-cropping system in central China. Eur. J. Agron. 45: 75-86.

Yaduvanshi, N. P. S. and D. R. Sharma. 2008. Tillage and residual organic manures/ chemical amendment effects on soil organic matter and yield of wheat under sodic water irrigation. Soil Tillage Res. 98: 11-16. 
" اثر روشهاى خاككورزى و كاشت.... مينا ابراهيمى و همكاران، 99"1، •94-19

\title{
Effect of tillage and planting methods on soil physical properties, grain yield and milling recovery of rice (Oryza sativa L. cv. Hashemi)
}

\author{
Ebrahimi, M., ${ }^{1}$ M. Majidian² and M. R. Alizadeh ${ }^{3}$
}

\begin{abstract}
Ebrahimi, M., M. Majidian, M. R. Alizadeh. 2020. Effect of tillage and planting methods on soil physical properties, grasin yield and milling recovery of rice (Oryza sativa L. cv. Hashemi). Iranian Journal of Crop Sciences. 22(1): 66-80. (In Persian).
\end{abstract}

To evaluate the effects of tillage and planting systems on soil physical properties, grain yied and its components, and milling recovery of rice (cv. Hashemi), an experiment was conducted at Rice Research Institute of Iran in 2017 and 2018 cropping seasons-using split plot arrangements in randomized complete block design with three replications. The experimental factors were; tillage methods (main plots) at three levels (rotary tractor, power tiller conventional puddler and power tiller rotary puddler), planting methods (sub plots) in three levels (manual transplanting, mechanized transplanting and direct seeding). Results of combined analysis of variance showed that fall-cone penetration depth and bulk density were significantly affected by tillage methods. Maximum penetration depth of fall-cone $(10.86 \mathrm{~cm})$ and minimum bulk density $\left(0.86 \mathrm{~g} . \mathrm{cm}^{-3}\right)$ were observed in tillage rotary tractor.Plant height $(144.01 \mathrm{~cm})$ and number of tillers per $\mathrm{m}^{-2}\left(344\right.$ tillers. $\left.\mathrm{m}^{-2}\right)$ in direct seeding were significantly higher than mechanized and manual transplanting methods. Maximum harvest index (49.29\%) and pushing resistance $(5.73 \mathrm{~N})$ in mechanized transplanting was significantly diffirent in comparison to manual transplanting and direct seeding. Maximum number of panicles. $\mathrm{m}^{-2}$ obtained in direct seeding $\left(288\right.$ panicles. $\left.\mathrm{m}^{-2}\right)$ followed by mechanized transplanting $\left(284\right.$ panicles. $\left.\mathrm{m}^{-2}\right)$ which were significantly diffirent from panicle number per unit area in manual transplanting (261 panicles. $\mathrm{m}^{-2}$ ). Effect of tillage methods, planting methods and their interaction on head rice, broken rice and milling recovery were not significant. It can be concluded that power tiller puddler, mechanized transplanting and direct seeding may improve grain yield components with maintaining the the soil physical properties.

Key word: Direct seeding, Mechanized transplanting, Pushing resistance, Rice and Tillage systems.

\footnotetext{
Received: April, $2019 \quad$ Accepted: December, 2019

1. PhD Student, University of Guilan, Rasht, Iran

2. Associate Prof., University of Guilan, Rasht, Iran (Corresponding author) (Email: ma_majidian@guilan.ac.ir)

3. Associate Prof., Rice Research Institute of Iran, Agricultural Research Education and Extension Organization, Rasht, Iran
} 